\begin{tabular}{|c|l|}
\hline Title & A lower trophic ecosystem model including iron effects in the Okhotsk Sea \\
\hline Author(s) & Okunishi, Takeshi; Kishi, Michio J.; Ono, Y ukiko; Y amashita, Toshihiko \\
\hline Citation & $\begin{array}{l}\text { Continental Shelf Research, 27(16), 2080-2098 } \\
\text { https://doi.org/L0.1016/.Crr.2007.05.007 }\end{array}$ \\
\hline Issue Date & 2007-09-15 \\
\hline Doc URL & http://hdl.handle.net/2115/32364 \\
\hline Type & article (author version) \\
\hline File Information & okunishiO7CSR.pdf \\
\hline
\end{tabular}

Instructions for use 


\title{
A Lower Trophic Ecosystem Model Including Iron Effects in the Okhotsk Sea
}

\author{
Takeshi Okunishi $^{1 *}$, Michio J. Kishi ${ }^{2,3}$, Yukiko Ono ${ }^{4}$, Toshihiko Yamashita ${ }^{1}$
}

${ }^{1}$ Graduate School of Engineering, Hokkaido University, Kita 13, Nishi 8, Kita-ku, Sapporo, 060-8628, Japan

2 Graduate School of Fisheries Sciences, Hokkaido University, Minato-cho 3-1-1, Hakodate, Hokkaido 041-8611, Japan

${ }^{3}$ Frontier Research Center for Global Change, 3173-25 Showamachi, Kanazawa-ku, Yokohama 236-0001, Japan

${ }^{4}$ Tokyo Dietitian Academy, 2-23-11 Ikejiri, Setagaya-ku, Tokyo 154-8544, Japan

*Corresponding author: Takeshi Okunishi

Graduate School of Engineering, Hokkaido University,

Kita 13, Nishi 8, Kita-ku, Sapporo, 060-8628, Japan

$\mathrm{Tel}+81-11-706-6184$

Fax $+81-11-706-6184$

E-mail: okunishi@eng.hokudai.ac.jp 


\begin{abstract}
We applied a three-dimensional ecosystem-physical coupled model including iron the effect to the Okhotsk Sea. In order to clarify the sources of iron, four dissolved iron compartments, based on the sources of supply, were added to Kawamiya et al.'s(1995) model (KKYS) to create our ecosystem model (KKYS-Fe). We hypothesized that four processes supply iron to sea water: atmospheric loadings from Northeastern Asia, input from the Amur River, dissolution from sediments and regeneration by zooplankton and bacteria. We simulated 1year, from 1 January, 2001 to 31 December, 2001, using both KKYS-Fe and KKYS. KKYS could not reproduce the surface nitrate distribution after the spring bloom, whereas KKYS-Fe agreed well with observations in the northwestern Pacific because it includes iron limitation of phytoplankton growth. During the spring bloom, the main source of iron at the sea surface is from the atmosphere. The contribution of riverine iron to the total iron utilized for primary production is small in the Okhotsk Sea. Atmospheric deposition, the iron flux from sediment and regeneration of iron in the water column play imp ortant roles in maintaining high primary production in the Okhotsk Sea.
\end{abstract}

(Keywords: ecosystem model, Okhotsk Sea, phy toplankton, iron, primary production) 


\section{INTRODUCTION}

The Okhotsk Sea is one of the most biologically productive regions in the world, which supports high fisheries production (Fig.1). Several previous reports indicate that the primary productivity of the Okhotsk Sea is very high, especially on the continental shelf (Sorokin and Sorokin, 1999; Saitoh et al., 1996). It has been rep orted that a major fraction of the phytoplankton in this sea are diatoms (e.g., Hanzawa et al., 1981), and previous observations revealed maximum diatom cell numbers in spring and minima in autumn (Ohwada, 1957; Hanzawa et al., 1981). The Okhotsk Sea is well-known as one of the southern most seasonal sea ice zones in the Northern Hemisphere. Matsumoto et al., (2004) analyzed the seasonal and interannual variability of chlorophyll-a (Chl-a) distributions in the Okhotsk Sea from 1998 to 2001. They concluded that the most important factor required to characterize the spatial and temporal variability of spring blooms was the timing of sea ice retreat, while a secondary factor was the changes in insolation. Okunishi et al., (2005) showed that the beginning of the spring bloom in the Okhotsk Sea depends on changes in the light environment, and that the presence of sea ice controls the light intensity in the surface water and thereby controls the timing of the spring bloom.

In recent years the micronutrient iron has been shown to play a key role in limiting phytoplankton growth rates and structuring plankton communities over much of the world's oceans, particularly in the high-nitrate, low-chlorophyll (HNLC) regions (Martin et al., 1989; Martin et al., 1990; Martin et al., 1991; Martin, 1992; Helbling et al., 1991; Price et al., 1994; Takeda and Obata, 1995; de Baar et al., 1995; Coale et al., 1996; Landry et al., 1997; Takeda, 1998; Behrenfeld and Kolber, 1999; Boyd and Harrison, 1999; Moore et al., 2000). Recent studies have shown that iron is an important factor controlling phytoplankton in the Western Subarctic Pacific (Tsuda et al., 2003). 
There are previous papers a concerning one-dimensional ecosystem model including the effect of iron applied to the HNLS regions (e.g. Peña 2003, Yoshie et al., 2005, Fujii et al., 2005). But, these models were not focused on iron cycling in the water column; rather, they examined the effect of iron on primary production without clarifying the sources of iron. On the other hand, three-dimensional computation including the iron cycle process can provide us with new knowledge of different sources of iron in primary production by clarifying these sources.

There is little information on iron concentration in the Okhotsk Sea. Tani et al. (2003) showed that $\mathrm{Fe}(\mathrm{III})$ solubility in the surface mixed layer was gen erally high and variable $(0.3-0.7 \mathrm{nM})$ in the southern Okhotsk Sea during May-June 2000. The inorganic nitrogen concentration varied in the upper mixed layer from 1 to $3 \mu \mathrm{M}$ in the center of the Okhotsk Sea in summer (Sorokin and Sorokin, 1999). Nitrate was depleted after the spring phytoplankton bloom in the western region of the Okhotsk Sea in June 2000 (Nakatsuka et al., 2004). These facts suggest that the iron supply is higher in the Okhotsk Sea than in the Western Subarctic Pacific and, that phytoplankton growth is not limited by iron availability in the Okhotsk Sea. However, it is not well-known whether iron or not limits phytoplankton growth, or what the main source of iron is in the Okhotsk Sea.

This study sought to evaluate the role of iron in biological production and to examine the sources of iron in the Okhotsk Sea by using a three-d imensional ecosystem-phy sical coupled model that includes iron bio geochemistry.

\section{Model Description}

\subsection{Ecological model}

\subsubsection{Structure}


Material flows in our ecosystem model are shown in Fig.2. This model is based on Kawamiy a et al. (1995) (referred to as KKYS hereinafter), which is a nitrogen-based model with 6 compartments (phytoplankton; Phy, zooplankton; Zoo, nitrate; $\mathrm{NO}_{3}$, ammonium; $\mathrm{NH}_{4}$, Detritus; D, dissolved organic matter; DOM). Four iron compartments were added, separated according to source as shown in Fig.2 (KKYS-Fe), to clarify the sources of iron. We assumed that the processes of dissolved iron supply to the Okhotsk Sea are: 1) atmospheric loadings from Northeastern Asia $\left.\left(\mathrm{FE}_{\mathrm{AIR}}\right), 2\right)$ riverine input from the Amur River $\left.\left(\mathrm{FE}_{\mathrm{RIV}}\right), 3\right)$ dissolution from sediments $\left(\mathrm{FE}_{\mathrm{SED}}\right)$, and 4) biological regeneration by zooplankton and bacteria $\left(\mathrm{FE}_{\mathrm{BIO}}\right)$ (Fig.3). The dissolved iron fraction from unidentifiable sources is also included in this compartment $\left(\mathrm{FE}_{\mathrm{BIO}}\right)$. We assumed that all dissolved iron is bioavailable and that particulate iron is not bioavailable (and therefore is omitted in the model). We also supp ose that the phytop lankton and zooplankton have the same iron/nitrogen ratio 0.044 in [nmol : $\mu \mathrm{mol}]$, assuming a carbon/nitrogen ratio of 106: 16 in phytoplankton, based on Gregg (2002) and Gregg et al. (2003). We used the same iron/nitrogen ratio in the other compartments (Detritus, DOM).

\subsubsection{Formulation of ecological processes}

Time evolution of each compartment is described as follows;

$$
\frac{\partial C_{i}}{\partial t}=-v \cdot \nabla C_{i}+\nabla(K \nabla C)+(\text { biological term })
$$

where $C_{i}$ is the arbitrary compartments, $v$ current velocity, and $K$ the diffusion tensor. The mathematical formulations for the nitrogen flow followed those of Kawamiya et al., (1995). The new and modified formulations are as follows:

Photosynthesis: The Michaelis-Menten formula was adopted for iron uptake by phytoplankton. 
Noiri et al., (2005) reported that the half-saturation constant for iron is $0.59 \mathrm{nM}\left(\right.$ at $5{ }^{\circ} \mathrm{C}$ ) and 0.58 $\mathrm{nM}$ (at $8^{\circ} \mathrm{C}$ ) for photosynthesis $(>10 \mu \mathrm{m}$ size fraction) in the Western Subarctic Pacific. In this model, 0.58 was used for $\left(K_{F F e}\right)$. Ammonium inhibition was taken into account (Wroblewski, 1977) in the original KKYS. We modified the half saturation constants (Moore et al., 2002) to account for the increased preference for ammonium under iron limitation. The half-saturation constant for nitrate uptake was increased to as much as $150 \%$ of its original value (Eqs.8 and 9) with increasing iron stress. Likewise, the half-saturation constant for ammonium was reduced to $50 \%$ of its original value with increasing iron stress (Eqs. 8 and 9).

$$
\begin{aligned}
& (\text { Photosynthesis })=G P P\left(P h y, N H_{4}, N_{3}, F e, T, I\right)=V_{\max }\{\min (L I M I T N, L I M E T F e)\} \times \exp (k T) \frac{I}{I_{\text {opt }}} \exp \left(1-\frac{I}{I_{\text {opt }}}\right) P h y \\
& I=I_{0} \exp (-\Lambda|z|) \\
& \Lambda=\alpha_{1}+\alpha_{2} \times P h y \\
& \text { LIMITN }=\left\{\frac{N O_{3}}{N O_{3}+K_{N O 3}}\right\} \times \exp \left(-\Psi N H_{4}\right)+\frac{N H_{4}}{N H_{4}+K_{N H 4}} \\
& \text { LIMITFe }=\frac{T F e}{F F e+K_{F e}} \\
& T F e=F E_{A I R}+F E_{R I V}+F E_{S E D}+F E_{B I O} \\
& T F e<K_{F e}: \begin{array}{l}
K_{N O 3}=K_{N O 3} \\
K_{N H 4}=K_{N H 4}
\end{array} \\
& T F e \geq K_{F e}: \begin{array}{l}
K_{N O 3}=K_{N O 3} \times 1.5 \\
K_{N H 4}=K_{N H 4} \times 0.5
\end{array}
\end{aligned}
$$

where $T$ is temperature, $z$ is depth, positive upward (zero at the sea surface), $I$ light intensity, $I_{\text {opt }}$ optimum light intensity, $I_{0}$ photosynthetically active radiation (PAR) at the sea surface, $\Lambda$ the light dissipation coefficient, and $T F e$ total dissolved iron concentration. Notation for parameters is given in Table 1 with their values. Parameters used to describe other processes are also given in this table. Here, the fraction of iron uptake from each compartment 
$\left(F E_{A I R}, F E_{R I V}, F E_{S E D}, F E_{B I O}\right)$ is defined as follows to simplify later discussion:

$$
R A F E=\frac{F E_{A I R}}{T F e}, \quad R R F E=\frac{F E_{R I V}}{T F e}, \quad R S F E=\frac{F E_{S E D}}{T F e}, \quad R B F E=\frac{F E_{B I O}}{T F e}
$$

Atmospheric iron flux: The main source of dissolved iron in the surface water in most areas of the open ocean is dust deposited at the sea surface (Duce and Tindale, 1991). The atmospheric iron flux is added to the first layer of the model at each time step of the ecological calculation. Duce and Tindale (1991) estimated the global atmospheric iron flux based on Donaghay et al. (1991), assuming that $3.5 \%(\mathrm{w} / \mathrm{w})$ of the atmospheric dust contributes to the iron flux. Fig.4 shows the annual iron flux in this study, based on Duce and Tindale (1991). Fung et al., (2000) estimated an iron budget for the upper ocean using solubilities of $1 \%$ and $10 \%$. We assumed that $1 \%$ of atmospheric iron is dissolved into the dissolved iron pool. We considered the seasonal variation in the iron flux by using the Gaussian function after Littmann (1991).

Iron flux from the A mur River: The Amur River is one of the largest rivers in East and North-East Asia. It is $4440 \mathrm{~km}$ long, and drains an area of 1,885,000 $\mathrm{km}^{2}$ and supplies significant freshwater to the Okhotsk Sea, The minimum discharge is about $1,000 \mathrm{~m}^{3} \mathrm{~s}^{-1}$ in March. Its discharge starts to increase in April, reaches a maximum (up to $200,000 \mathrm{~m}^{3} \mathrm{~s}^{-1}$ ) in September, gradually decreases in October to December, and then remains near the minimum level (Fig.5). The major part of the drainage area is underlain by boreal forest, mixed forest and swamps. The dissolved iron concentration of the Amur River is $0.56( \pm 0.17) \mathrm{mg} \mathrm{L}^{-1}$ (Shibata, 2005). It is well-known that salinity play s an important role in the aggregation process of dissolved iron in an estuary. Colloidal iron definitely plays a leading role in controlling iron behavior in the mixing process in estuaries, and its flocculation is responsible for the removal of dissolved iron (Dai and Martin, 1995). Sholkovitz (1976) pointed out that $100 \%$ of riverine iron is precipitated by flocculation under the 
influence of oceanic salinities. On the other hand, about $93 \%$ of dissolved iron in the Lena River was removed at the mouth of the Laptev Sea (Guieu et al, 1996). Predue et al. (1976) found a strong correlation between dissolved organic matter (fulvic acid) and iron concentration in natural waters. Figures et al. (1978) rep orted that organically-bound iron in river water can remain without sinking and is diffused into coastal water. Now, we assumed that $99 \%$ of the riverine iron is lost in the estuary, so that $1 \%$ of the riverine iron was the fluvial iron, and the dissolved iron concentration supplied to the Okhotsk Sea from the Amur River is $100 \mathrm{nM}$. FE $E_{\mathrm{RIV}}$ only includes a temporal input from the Amur River. The Amur River obviously supplies large amounts of particulate iron. The particulate iron has a potential to supply dissolved iron in the water column by resolution. Therefore, we included $\mathrm{FE}_{\mathrm{RIV}}$ as a "direct contribution" from the Amur River. And we did not include iron removed by flocculation at the river mouth (Fig.3), which must be recycled through re-suspension.

Iron solution from sediment: The iron flux from sediments to the Okhotsk Sea is not well-known. Kuma et al. (2000) reported that the soluble iron concentration was from 3 to $13 \mathrm{nM}$ near the bottom of Funka Bay. We expressed an effect of iron solution from sediments by fixing a high iron concentration $\left(\mathrm{FE}_{\mathrm{SED}}=13 \mathrm{nM}\right)$ in the bottom layers of the model.

Scavenging of dissolved iron: As a nutrient, iron behaves differently than nitrate, because it is scavenged from the dissolved phase by sinking particles. The abiotic scavenging rates for iron in sea water are not well-known; however, van den Berg (1995) and Rue and Bruland (1995, 1997) pointed out that at low iron concentrations $(<\sim 0.6 \mathrm{nM})$ most $(>99 \%)$ of the dissolved iron is bound to organic ligands, and is not strongly reactive with particles. Johnson et al., (1997) argued that scavenging was negligible due to ligand binding under low iron concentrations $(<\sim 0.6 \mathrm{nM})$. We have adopted a particle scavenging loss term for dissolved iron based on Moore et al., (2002). At 
low iron concentrations $(<0.6 \mathrm{nM})$ most dissolved iron is bound to organic ligands, but is still weakly reactive with particles, and above $0.6 \mathrm{nM}$, particle scavenging rates increase rapidly with increasing iron concentrations. Thus, below $0.6 \mathrm{nM}(T F e \leq 0.6 \mathrm{nM})$ we include a weak scavenging loss of $1.67 \%$ per year (Eq. 11). As iron concentrations exceed this threshold $(T F e>0.6 n M)$, scavenging increases with increasing iron concentrations following Michaelis-M enton type kinetics up to a maximum rate of $2.74 \%$ per day with a half-saturation constant of $1.8 \mathrm{nM}$ (Eq. 11). We assumed that scavenged iron was removed from the iron pool of the ecosystem, i.e., iron is not conserved in the model.

$$
\begin{aligned}
& T F e \leq 0.6 n M:(\text { Scavenging })=2.74 \times 10^{-5} \times T F e[n M / \text { day }] \\
& T F e>0.6 n M:(\text { Scavenging })=\left(2.74 \times 10^{-5} \times 0.6\right)+(0.0274 \times(T F e+0.6)) \times \frac{(T F e-0.6)}{(T F e+1.4)}[n M / \text { day }]
\end{aligned}
$$

\subsubsection{Governing equations}

Combining the biochemical processes formulated above and Kawamiya et al., (1995), $t$ governing equations of iron are:

$$
\begin{aligned}
\frac{\partial F E_{A I R}}{\partial t}= & (\text { Iron flux from atmosphere: fist layer only }) \\
& +R A F E \times(-(\text { Photosynthesis }) \times R F N-(\text { Scavenging }))+\operatorname{Dif}\left(F E_{A I R}\right)+A d v\left(F E_{A I R}\right) \\
\frac{\partial F E_{R I V}}{\partial t}= & (\text { Riverine input }: \text { the mouth of the Amur River only }) \\
& +R R F E \times(-(\text { Photosynthesis }) \times R F N-(\text { Scavenging }))+\operatorname{Dif}\left(F E_{R I V}\right)+A d v\left(F E_{R I V}\right) \\
\frac{\partial F E_{S E D}}{\partial t}= & (\text { input from sediment :fixed } 0.8 \mathrm{nM} \text { in the bottom layers }) \\
& +R S F E \times(-(\text { Photosynthesis }) \times R F N-(\text { Scavenging }))+\operatorname{Dif}\left(F E_{S E D}\right)+A d v\left(F E_{S E D}\right) \\
\frac{\partial F E_{B I O}}{\partial t}= & R B F E \times\left(\begin{array}{l}
-(\text { Photosynthesis }) \times R F N-(\text { Scavenging })+(\text { Excretion }) \\
+\left(\text { Decomposition of POM into } \mathrm{NH}_{4}\right)+\left(\text { Decomposition DOM into } \mathrm{NH}_{4}\right)
\end{array}\right) \\
& +\operatorname{Dif}\left(F E_{R I V}\right)+A d v\left(F E_{R V}\right)
\end{aligned}
$$

\subsubsection{Initial condition}


To remove the effects of the initial conditions for the ecological compartments, we first ran the ecosy stem model starting with our best estimates for the initial condition under the 2001 forcing for one year. The concentrations at this end of the spin-up were used as the initial conditions for the simulation. The best estimates of the initial values for the spin-up were as follows:

$\mathrm{NO}_{3}$ : The climatological data from the World Ocean Atlas 2001 (WOA 2001) are used, $\mathrm{FE}_{\mathrm{BIO}}$ : Defined by Fig.6 as a function of depth based on Fe(III) solubility by Tani et al. (2003),

$$
\begin{aligned}
& \mathrm{NH}_{4}=\mathrm{D}=\mathrm{DON}=0.0 \mu \mathrm{M}-\mathrm{N}, \\
& \mathrm{Phy}=0.1 \mu \mathrm{M}-\mathrm{N} \\
& \mathrm{ZOO}=0.01 \mu \mathrm{M}-\mathrm{N}, \\
& \mathrm{FE}_{\mathrm{AIR}}=\mathrm{FE}_{\mathrm{RIV}}=0 \mathrm{nM}-\mathrm{Fe} .
\end{aligned}
$$

Figure 7 shows the time-dependent features of the ecological compartments in the surface lay er (0-20 m) at Sta.C (see Fig.1) for two years. The first-year results are a spin-up integration, the second-year results are used for model analy sis. The time constants of this ecosy stem model are less than 160 days.

\subsection{Physical model}

The Princeton Ocean Model (POM) (Blumberg and Mellor, 1987; Galperina and Mellor, 1990) was used for the ocean model. This model is a three-dimensional, free surface, ocean model with a second moment turbulence closure scheme (Mellor and Yamada, 1982) to provide vertical mixing coefficients. The model domain extends from $34^{\circ} \mathrm{N}$ to $63^{\circ} \mathrm{N}$ and from $127^{\circ} \mathrm{E}$ to $166^{\circ} \mathrm{E}$, which does not include the Japan Sea (Fig.1). The Soya and Tsugaru Straits are closed, and grids shallower than 
$30 \mathrm{~m}$ depth are masked. The horizontal grid scale is $1 / 6^{\circ}$. POM uses a sigma coordinate system in the vertical dimension. In deep areaa, a sigma coordinate system cannot resolve adequately near the surface, because the layer thickness becomes large. Therefore, the fixed z-levels coordinate system is used for the upper 10 levels, while the lower 10 levels are sigma levels. The thicknesses of the upper 10 levels are $2 \mathrm{~m}$. The following surface drag coefficients were used;

$$
\begin{aligned}
& C_{d}=1.6^{*} 10^{-3} \text { for } \mathrm{W}<7 \mathrm{~m} / \mathrm{s} \\
& C_{d}=2.5^{*} 10^{-3} \text { for } \mathrm{W}>10 \mathrm{~m} / \mathrm{s}
\end{aligned}
$$

with a smooth transition for wind speeds between 7 and $10 \mathrm{~m} / \mathrm{s}$ (Csandy, 1982). The time steps for calculating the baroclinic (internal mode) and barotropic (external mode) cycles were taken as 300 and 10 seconds, respectively. At the solid walls of the boundary the normal components of the velocity were set to zero, while at the open boundaries of the computational domain, we specified the conditions of radiation and smoothing of the tangential component. For the sea elevation at these open boundaries, a non-gradient condition was assumed. If temperature and salinity were advected into the model domain by inflow at open boundaries, the temperature and salinity of the WOA 2001 monthly data were used to interpolate for each time step. Under outflow conditions, the radiation condition is adapted at the op en boundary. The climatological data from the WOA 2001 is also used as the initial conditions of temperatures and salinity. We applied the Orlanski method (Orlanski, 1976) as open boundary conditions of the ecological compartments. The model is run for 250 days in a diagnostic mode (holding the density field unchanged) to obtain the velocity and the sea surface height field using the climatological wind stress of daSilva et al.,(1994). After this initial run, the physical fields are used for the initial condition of the coupled model.

Sea ice effect: In this study we used the NCAR Climate System Sea ICE Model (Bettge et al., 
1996). The momentum dynamics in the above model are based on the model by Flato and Hibler (1992). The thermodynamics of ice growth and melting processes are taken from Semtner (1976), Parkinson and Washington (1979), Harvey (1988) and Pollard and Thompson (1994). Sea ice affects the momentum in the ocean model and the light under ice in the ecological model. The estimated momentum flux and light intensity under ice are as follows.

(Momentum flux under sea ice): Under sea ice, there is a momentum flux from the atmosphere to the surface water, via the sea ice. The momentum flux in the ocean model is $\tau_{x}=\tau_{a}+\tau_{i}, \tau_{a}$ is the moment flux from the atmosphere to the surface water, $\tau_{i}$ is the moment flux from the sea ice to the surface water. The momentum flux from the atmosphere to the surface water is described as: $\tau_{a}=\rho C_{d} W_{x} \sqrt{W_{x}^{2}+W_{y}^{2}}(1-I C / 100)$ (23) where, $\rho$ is the sea water density, $C_{d}$ is the drag coefficient $W_{x}$ is the zonal wind speed, $W_{y}$ is the meridional wind speed, and $I C$ is the sea ice concentration in per cent. The momentum flux from the sea ice to the surface water is described as: $\tau_{i}=\rho_{w} C_{D W}\left|u_{i}-u_{w}\right|\left(u_{i}-u_{w}\right)(I C / 100)$ (24) where $\rho_{w}$ is the surface water density, $C_{D W}$ is drag coefficient $\left(4^{*} 10^{-3}\right), u_{i}$ is the sea ice velocity, $u_{w}$ is the surface water velocity.

(Light condition under sea ice): The incident light strength under sea ice $\left(I_{d}\right)$ is described as follows:

$$
I_{d}=I_{0}(1-r) e^{-\alpha \cdot d} \times(1-I C / 100)
$$

where, $I_{0}$ is the incident light strength at the surface of sea ice, $r$ is the reflectivity at the sea ice surface, $d$ is the thickness of sea ice and $\alpha$ is the extinction coefficient of sea ice. Gilgert and Buntzen (1984) reported that the extinction coefficient in sea ice of $10 \mathrm{~cm}$ thickness was $0.025 \mathrm{~cm}^{-1}$. We used this value. Ishikawa et al (2003) reported the value of 0.04 as the reflectivity at the sea ice surface, and this value is used in our model. The thickness of sea ice is estimated by the sea ice 
model described above.

\subsection{Model run}

The simulation was conducted for one year from 1 January, 2001 to 31 December, 2001. In 2001 a large ice-coverage was observed in the Okhotsk Sea; the maximum ice area was about $99 \%$ in the winter. The momentum fluxes are calculated with the zonal and meridional wind speeds from the National Centers for Environmental Prediction and the National Center for Atmospheric Research (NCEP/NCAR) reanalysis data (Kalnay et al., 1996). The heat fluxes are estimated from the short wave radiation, air temperature, air pressure, relative humidity and the cloud function from NCEP daily reanalysis data. The formulate of these fluxes are based on Wang et al. (2005). The Amur River discharge is obtained from the Global Runoff Data Centre (monthly mean data from 1933 to 1990) (Fig.5). The surface salinity values are restored to the National Oceanographic Data Center (NODC) climatological monthly mean values (Levitus and Boyer, 1994), with a decay term $\gamma\left(S^{*}-S\right)$ for the salinity equations at the surface grids, where $S$ is the sea surface salinity (SSS), $S^{*}$ is the climatological data, and $\gamma(=\Delta t / \kappa, \Delta t:$ the time step for the internal mode $)$ is the so called nudging constant. $\kappa$ is the 20 day. The effects of precipitation and evaporation as well as river disch arge are included by applying the SSS data from NODC. The Amur River discharge, sea ice formation and melting are also reflected as SSS data. We also used Bishop and Rossow's (1991) monthly mean solar radiation data as PAR (photosynthetically active radiation). 


\section{RESULTS and DISCUSSION}

\subsection{Nitrate, Chl-a and iron concentration}

According to Okunishi et al. (2005), the presence of sea ice controls light intensity in the surface water and thereby controls the timing of the spring bloom in the Okhotsk Sea. The reproducibility of the sea ice model is an important factor to enhance the credibility of the ecosy stem model. Figure 8 shows the monthly sea ice concentrations from NCEP data (Reynolds et al., 2002) and the model results. The model can reproduce the seasonal prevalence of sea ice in the Okhotsk Sea in 2001. Saitoh et al. (1996) showed that the spring bloom usually occurred between April and May in the Okhotsk Sea based on the monthly coastal zone color scanner (CZCS)-chlorophyll (Chl) imagery from 1978 until 1986. Figure 9 shows the time-dependent features of Chl-a concentrations and nitrate concentrations in the surface layer $(0-20 \mathrm{~m})$ at five stations (see Fig.1). Chl-a concentrations estimated by both KKYS-Fe and by KKYS coincide with the time variation of the SeaWiFS(Sea-viewing Wide Field-of-view Sensor) features in all stations. Nitrate concentrations estimated by KKYS-Fe and KKYS also agree with the seasonal variation of the WOA 2001's nitrate concentrations at all stations except at Sta.E (northwestern Pacific). At Sta.E the nitrate concentration is underestimated by KKYS, and the Chl-a concentration is overestimated in spring (Fig.9). The spring bloom peak estimated by KKYS-Fe occurs slightly later than in SeaWiFS except for Sta. A. Generally, in ecosystem models, the photosynthesis rate is one of the important factors that determines the timing and scale of spring blooms (Fujii et al, 2002; Okunishi et al, 2005). In our model, the value of the half-saturation constant for iron uptake, which is based on the incubation experiment by Noiri et al (2005), is higher than that of previous ecosystem models including the effect of iron(e.g. Moore et al., 2002). Thus, in our model, 
photosynthesis rate estimated by KKYS-Fe is lower than the KKYS estimate even in the Okhotsk Sea at the high iron concentration. In KKYS-Fe this low photosynthesis rate causes a delay of one month in the spring bloom compared with the KKYS result, which showed good agreement with SeaWIFS data. However, the Chl-a concentration estimated by KKYS is higher than that of SeaWIFS during winter (Jan. Mar.) and the pre-blooming season ( Apr.) at all stations. And during these months, nitrate estimated by KKYS is underestimated compared with the WOA 2001 data. Additionally, the primary production over the Okhotsk Sea estimated by KKYS is slightly higher compared with previous estimations (see Section 3.2). Therefore, in the surface layer, the nitrogen budget is reproduced better by KKYS-Fe than by KKYS.

Figure 10 shows the sea surface nitrate distribution simulated by KKYS and KKYS-Fe together with the observed value from the WOA 2001 in March. In March, before the spring bloom, the results of KKYS-Fe agree well with the observation, but those of KKYS do not agree in the northwestern Pacific. As shown in Fig.10 (a, b), the nitrate concentration is relatively high in the northwestern Pacific. After the spring bloom (July), the sea surface nitrate is depleted in almost all areas of the Okhotsk Sea and the concentration remains more than $5 \mu \mathrm{M}$ in the northwestern Pacific (Fig.11a). KKYS-Fe (Fig.11b) shows almost the same features as the WOA 2001 data in both the Okhotsk Sea and the northwestern Pacific. On the other hand, KKYS can never reproduce this surface nitrate distribution (Fig.11c), but the sea surface nitrate is depleted in almost the whole area.

The spring bloom in 2001 begins in the southern and northeastern parts of the Okhotsk Sea in May, and moves toward the northern and northeastern parts in June (Fig.12a, Fig.13a). Both KKYS and KKYS-Fe can reproduce the spatial distribution of phytoplankton during the spring bloom in the Okhotsk Sea (Fig. 12b, c, Fig. 13b, c). Figure 14 shows the horizontal distribution of each iron 
compartment at the sea surface in June (during the spring bloom). Most of the iron near the sea surface in the Okhotsk Sea comes from the atmosphere $\left(\mathrm{FE}_{\mathrm{AIR}}\right)$. In the western Okhotsk Sea, the surface $\mathrm{FE}_{\mathrm{AIR}}$ concentration is high $(>0.6 \mathrm{nM}-\mathrm{Fe})$, while in the eastern Okhotsk Sea it is low $(<0.4$ nM-Fe) (Fig.14a). This pattern agrees with the source of the atmospheric iron flux (Fig.4). The surface $\mathrm{FE}_{\mathrm{SED}}$ concentration is high $(>0.5 \mathrm{nM})$ around the costal zone of Okhotsk Sea in June (Fig. 14b). The surface $\mathrm{FE}_{\mathrm{BIO}}$ concentration is low in the northern Okhotsk Sea $(>0.4 \mathrm{nM}-\mathrm{Fe})$ (Fig.14c). This pattern of $\mathrm{FE}_{\mathrm{BIO}}$ distribution agrees with the inverse Chl-a distribution. This shows that the $\mathrm{FE}_{\mathrm{BIO}}$ distribution depends on the consumption of surface iron by phytoplankton. The surface $\mathrm{FE}_{\mathrm{RIV}}$ concentration is high only near the mouth of Amur River in May (Fig.14d), when its maximum concentration is about $3 \mathrm{nM} \mathrm{Fe}$.

The surface Chl-a distribution from KKYS-Fe agrees well with the SeaWiFS-Chl image, with respect to the low Chl-a feature in the northwestern Pacific. This suggests that a strong iron limitation exists in the northwestern Pacific. It is well-known that the Western North Pacific is a high-nutrient, low-chlorophyll (HNLC) region. A meso-scale in situ iron enrichment experiment, SEEDS (Subarctic Pacific Iron Experiment for Ecosystem Dynamics Study), clearly demonstrated that iron fertilization stimulated the utilization of surplus nutrients and the uptake of carbon dioxide by phytop lankton (Tsuda et al., 2003). In our simulation, low $\mathrm{FE}_{\mathrm{AIR}}$ concentrations at the sea surface overlapped with areas of high nitrate concentration (Fig.11b, Fig.14a). It is clear that this region is HNLC because of a low atmospheric iron flux and iron limitation of phytoplankton growth.

Off the east coast of Kamchatka Peninsula, the Chl-a concentration in the SeaWiF S-Chl images is relatively high in May (Fig.12a). However, KKYS-Fe shows a low Chl-a concentration in this region (Fig.12b) due to iron limitation of phytoplankton growth. This discrepancy may be 
explained by another iron source near the east coast of Kamchatka Peninsula. For example, the iron flux in dust is very high near Kamchatka Peninsula due to active volcanoes (unpublished data). The iron supply from volcanoes may cause a high Chl-a concentration around Kamchatka Peninsula. In the northwestern Pacific, the nitrate concentration estimated by KKYS-Fe is lower than the WOA 2001 data, in particular, near the open boundary (Fig.10a, b and Fig.11 a, b). We can presume that this high nitrate concentration is caused by the effect of advection by the Oyashio Current, which brings water with high nitrate and low dissolved iron concentration from the HNLC regions in the Western Subarctic Pacific. The Orlanski method which we used as the open boundary condition, cannot reproduce well the effect of advection and seasonal variations in nitrate and dissolved iron concentration. As another discrepancy, in the central Okhotsk Sea, the Chl-a concentration in the model is higher than SeaWiFS data during the bloom season (Fig.13 a,b). Okunishi et al. (2005) found that the Chl-a concentration was also low in this region in 1997. If iron limitation causes low Chl-a levels in this region during the bloom season, the iron flux is overestimated in our model. $\mathrm{FE}_{\mathrm{RIV}}$ and $\mathrm{FE}_{\mathrm{SED}}$ are much lower than $\mathrm{FE}_{\mathrm{AIR}}$, and also $\mathrm{FE}_{\mathrm{BIO}}$ in the Okhotsk Sea is almost the same level as that in the northwestern Pacific (Fig.14). Consequently, the over-estimated portion of the iron flux must come from the atmospheric iron flux.

\subsection{Primary production in the Okhotsk Sea}

The estimated mean primary production over the Okhotsk Sea is $382 \mathrm{~g}-\mathrm{C} \mathrm{m}^{-2} \mathrm{year}^{-1}$ for KKYS and $310 \mathrm{~g}-\mathrm{C} \mathrm{m}$ year $^{-1}$ for KKYS-Fe. Previous estimations of total annual primary production in the Okhotsk Sea were in the range of 100-200 $\mathrm{g}^{-C ~ \mathrm{~m}^{-2}} \mathrm{year}^{-1}$ (Nishimura 1983; Ivanenkov and Zemlyanov, 1985) while recent estimates are rather higher (e.g., 313-355 g-C m m $^{-2}$ year $^{-1}$ from 
Sorokin and Sorokin, 2002). Figure 15 shows the horizontal distribution of primary production by KKYS-Fe. The high primary production is found around the Kuril Islands and the southeastern Okhotsk Sea, where the iron is supplied from the atmosphere and sediments. Figure 16 shows the difference in annual primary production between KKYS and KKYS-Fe. Areas with large differences are where iron strongly limits phytoplankton growth. According to this figure, iron is most limiting in the southeastern Okhotsk Sea.

Figure 17 shows the time dependent features of the fractional contribution from each source of iron to total photosynthesis in the Okhotsk Sea. Atmospheric iron (photosynthesis using $\mathrm{FE}_{\mathrm{AIR}}$ ) contributed about $33 \%$ by year (Table 2). Especially during the spring bloom, its contribution is the highest of the four dissolved iron compartments, reaching a maximum of $41 \%$ (Fig.17). Duce and Tindale (1991) pointed out that dust deposition is the main source of dissolved iron at the sea surface in the open ocean. The iron deposited in surface water is generally consumed very rapidly by phytoplankton (Johnson et al., 1997). In fact, even in the Okhotsk Sea (a marginal sea), the majority of primary production depends on atmospheric iron during the spring bloom, according to our results. Biologically regenerated iron $\left(\mathrm{FE}_{\mathrm{BIO}}\right)$ contributed about $33 \%$ of the primary production in the Okhotsk Sea by year (Table 2). This suggests that $\mathrm{FE}_{\mathrm{BIO}}$ also plays an important role in maintaining high primary production in the Okhotsk Sea. The iron from sediment $\left(\mathrm{FE}_{\mathrm{SED}}\right)$ also has a significant contribution as dissolved iron source (32\%) per year (Table 2). On the other hand, the contribution of riverine iron ( $\left.\mathrm{FE}_{\mathrm{RIV}}\right)$ is small. Even during the period with a large iron input from the Amur River in summer, the maximum contribution of $\mathrm{FE}_{\mathrm{RIV}}$ is only $4.3 \%$ (Fig.17).

\subsection{Sensitivities to the atmospheric, sediment and riverin iron fluxs}


To investigate the sensitivity to the atmospheric iron flux, the iron flux from sediment and the riverine iron flux from the Amur River against the primary production, we conducted simulations by changing the iron flux with the same physical conditions. Case 1 is the default condition described in the previous section. In Case 2, we set the atmospheric iron flux to be half that in Case 1. In Case 3, $\mathrm{FE}_{\mathrm{SED}}$ in the bottom layers is fixed to be $5 \mathrm{nM}$ which is almost one-third that in Case 1. In Case 4, we set the iron flux from the Amur River to be ten times that in Case 1. Other conditions in Case 2, Case 3 and Case 4 are exactly the same as in Case 1 . Table 2 shows the contribution of four iron sources to annual primary production in the Okhotsk Sea. In all cases, the atmospheric iron flux, the iron flux from sediment and the biologically recycled iron have strong impacts on the primary production. In case2, however, the contribution of $\mathrm{FE}_{\mathrm{AIR}}$ to primary production is lower $(21 \%)$ than in case 1 because of the decrease of the iron flux from atmosphere. The uptake ratio from the other sources of iron changes, and consequently the primary production using the other sources becomes a little bit larger. But total primary production is reduced due to the decrease in the input from the atmosphere. In Case 3, as is shown in Fig.14b, the contribution from sediment is extremely high near the coast of eastern Okhotsk, where the input from the atmosphere is small. This is the reason why the total primary production is reduced in Case 3 .

In Case 4, the contribution of $\mathrm{FE}_{\mathrm{RIV}}$ to primary production is higher than in case 1. Although iron flux from the Amur River is ten times larger than in case 1, however, the contribution of FE $E_{\mathrm{RIV}}$ is not necessary high in Case 4. This is because that the scavenging effect is significant as the cause of the high dissolved iron concentration. Large amounts of $\mathrm{FE}_{\mathrm{RIV}}$ are removed around the coastal estuary of the Amur River. In our model, the role of riverine iron in the primary production is small. However, the Amur River supplies iron into the Okhotsk Sea in the form of particulate iron moving 
through the estuary. The riverine iron from the Amur River is potentially the source of FE $E_{\text {SED. }}$ Additionally, iron from unidentified sources is included in the standing stock of $\mathrm{FE}_{\mathrm{BIO}}$. There is a possibility that the main source of $\mathrm{FE}_{\mathrm{BIO}}$ is riverine iron from the Amur River. The contribution of dissolved iron from the Amur River for primary production is small according to our results, because our model only considers "a direct contribution" (see Fig.3) of iron from the Amur River. $\mathrm{FE}_{\mathrm{BIO}}$ must include recycled iron, the source of which is originally from the river. In addition to this, we assumed that $99 \%$ of riverine iron from the Amur was removed from the model system because dissolved iron aggregates and sinks in the estuary. The uncertainty of this assumption prevents us from obtaining a precise estimate of the contribution of riverine iron to primary production in the Okhotsk Sea. Aggregated iron could be re-suspended by strong tidal currents (Ohshima et al., 2002) and strong vertical mixing in the continental shelf in winter, and be resolved in the water column. This indirect contribution may play a large role in the iron cycles in the Okhotsk Sea.

In this study, we applied average values for the atmospheric iron flux. The surface $\mathrm{FE}_{\mathrm{AIR}}$ concentration is high in May in the southern Okhotsk Sea. Consequently, the surface TFe concentration is high compared to the observations in May. The atmospheric iron flux may have been overestimated in this study. We have no definite information on atmospheric iron fluxes in the Okhotsk Sea. It is important to accurately quantify atmospheric iron fluxes to the sea surface in marginal seas as well as the iron concentration in the water column. We encourage further research concerning this point. In further work, it will be necessary to develop an ecosystem model including a complete iron cycle, and to estimate more accurately the sources of iron using long-term simulations with that model. 


\section{CONCLUSIONS}

This study is the first to examine the iron sources in the Okhotsk Sea by using an ecosystem model including the effects of iron. Our results suggest that atmospheric deposition, the iron flux from sediment and biological regeneration of iron in the water column play an important role in maintaining high primary production in the Okhotsk Sea. The contribution to primary production of the atmospheric dep osition of iron $\left(\mathrm{FE}_{\mathrm{AIR}}\right)$ during the spring bloom in the Okhotsk Sea is extremely large. In addition, biologically regenerated iron $\left(\mathrm{FE}_{\mathrm{BIO}}\right)$ is important through out the year.

\section{ACKNOWLEDGEMENTS}

We would like to thank Dr. Ohshima of Hokkaido University for his fruitful discussions. We wish to express our thanks to Dr. S. Lan Smith of Frontier Research Center of Global Change for his valuable comments and his help proof reading the manuscript. We also appreciate the valuable comments of anonymous referees. This paper is a contribution to the Amur-Okhotsk Project (Human Activities in Northeastern Asia and Their Impact on the Biological Productivity in North Pacific Ocean), promoted by the Research Institute for Humanity and Nature (RIHN).

\section{REFERENCES}

Behren feld, M. J., Kolber, Z. S., 1999. Widespread iron limitation of phytoplankt on in the south pacific ocean. Science, $283,840-843$

Bettge T. W., J. W. Weatherly, W. M. Washington, D. Pollard, B. P. Briegleb, W. G. Strand Jr., 1996. The NCAR CSM Sea Ice Model, NCAR Technical Note, TN-425+ST R, National Center for Atmospheric Research, Boulder, Colorado, $30 \mathrm{pp}$.

Bishop, J. K. B., Rossow W. B., 1991. Spatial and temporal variability of global surface solar irradiance. J. 
Geophys. Res. 96, 16839-16858

Blumberg, A. F., Mellor G. L., 1987. A description of a three-dimensional coastal ocean circulation model. In: Heaps, N.S., Editor, Three-dimensional Coastal Ocean Models Coastal and Estuarine Sciences vol. 4, AGU, Washington, 1-16

Boyd, P., Harrison, P. J., 1999. Phytoplankton dynamics in the NE subarctic Pacific. Deep-Sea Research II , 46, $2405-2432$

Coale, K.H., Johnson, K.S., Fitzwater, S.E., Gordon, R.M., Tanner, S., Chavez, F.P., Ferioli, L., Sakamoto, C., Rogers, P., Millero, F., Steinberg, P., Nightingale, P., Cooper, D., Cochlan, W.P., Landry, M.R., Constantiou, J., Rollwagen, G., Trasvina, A., Kudela, R., 1996. A massive phytoplankton bloom induced by an ecosystem-scale iron fertilization experiment in the equatorial Pacific Ocean. Nature, $383,495-501$

Csandy, G. T., 1982. Circulation in the Coastal Ocean. D. ReidelP ublishing Co., Dordrecht, Holland. 279pp. daSilva, A. M., Yong, C. C., Levitus, S., 1994. Atlas of Surface Marine Data NOAA.

de Baar, H.J.W., de Jong, J.T.M., Bakker, D.C.E., L.oscher, B.M., Veth, C., Bathmann, U., Smetacek, V., 1995. Importance of iron for plankton blooms and carbon dioxide drawdown in the Southern Ocean. Nature, $373,412-415$

Donaghay, P.L., Liss, P.S., Duce, R.A., Kester, D.R., Hanson, A.K., Villareal, T., Tindale, N.W., Gifford, D.J., 1991. The role of episodic atmospheric nutrient inputs in the chemical and biological dynamics of oceanic ecosy stem s. Oceanography, 4, 2, 62-70.

Duce, R.A., Tindale, N.W.,, 1991. Atmospheric transport of iron and its deposition in the ocean. Limnology and Oceanography, 36, $17155-1726$

Figures, G., Martin, J. M., Meybeck, M., 1978. Iron behavior in the Zaire Estuary. Netherlands Journal of Sea Research 12, 329-337.

Flat o, G. M., Hibler W. D., 1992. Modeling pack ice as cav it at ing fluid. J. Phys. Oceanogr. 22, 626-651.

Fujii, M., Nojiri Y., Yamanaka Y., Kishi M.J., 2002. A one-dimensional ecosystem model applied to time series Station KNOT. Deep Sea Research. P art 2,49, 5441-5461.

Fujii M., Yoshie N., Yamanaka Y., Chai F., 2005. Simulated biogeochemical responses to iron enrichments in three high nutrient, low chlorophyll (HNLC) regions. Progress in oceanography, 64, 307-324.

Fung, I.Y., Meyn, S.K., Tegen, I., Doney, S.C., John, J.G., Bishop, J.K.B., 2000. Iron supply and demand in the 
upper ocean. Global Biogeochemical Cycles, 14, 281-291

Galperina, B., Mellor, G. L., 1990. A time-dependent, three-dimensional model of the Delaware Bay and River system. Part 1: Description of the model and tidal analysis. Estuarine, Coastal and Shelf Science, 31, 231-253.

Gilgert, G. D., Buntzen, R. R., 1984. In-situ measurem ents of the optical propert ies of arctic sea ice. SP IE Vol.637 Ocean Optics 8, 232-263

Gregg, W.W., 2002. Tracking the SeaWiFS record with a coupled physical/biogeochemical/radiat ive model of the global oceans. Deep-Sea Research II , 49, 81-105

Gregg, W.W., Ginoux, P., Schopf, P.S., Casey, N.W., 2003. Phytoplankton and iron: validation of a global three-dimensional ocean biogeochemical model. Deep-Sea Research II , 50, 3143-3169

Guieu, C., Huang, W-W., Martin, J-M., Yong, Y-Y., 1996. Out flow of trace metal into the Laptev Sea by the Lena River. Marine Chemistry, 53, 255-267

Hanzawa, M., Iida, H., Karasushi, K., Matsuzaki, M., Shigehara, K., Kuromuma, S., Akagawa, M., Asaoka, O., 1981. Studies on the mechanism of formation of cold water in the Okhotsk Sea, p. 66-131. In Report of Joint-Research on the Okhotsk Sea, ed. Research Coordination Bureau, Science \& Technology Agency. Science \& Technology Agency, Tokyo., In Japanese)

Harvey, L.D.D., 1988. Development of a sea ice model for use in zonally averaged energy balance climate models. J. Clim. 1, 1221-1238.

Helbling, E.W., Villafa ne, V., Holm-Hansen, O., 1991. Effect of iron on productivity and size distribution of Antarctic phytoplankton. Limnology and Oceanography, 36, 1879-1885

Ishikawa,N., Takizawa,A., Kawamura,T., Shirasawa,K. and Lepparanta,M., 2003. Changes of the radiation property with sea ice growth in Saroma Lago on and the Baltic Sea. Report Series in Geophysics, 46, $147-160$

Ivanenkov, B.Z., Zemlyanov I. V., 1985. Oxygen and carbon production at a photosynthesis in the Okhotsk Sea. Izvestia TINRO, 110.151-152, in Russian)

Johnson, K. S., Gordon, R. M., Coale, K. H., 1997. What controls dissolved iron concentrations in the world ocean?. Marine Chemistry, 57, 137-161

Kalnay, E., Kanamitsu, M., Kistler, R., Collins, W., Deaven, D., Gandin, L., et al., 1996. The NCEP/NCAR 40-Year Reanaly sis Project, Bull. Am. Meteorol. Soc., 77, 3), pp. 437-470 
Kawamiya, M., Kishi, M. J., Yamanaka, Y., Suginohara, N., 1995. An ecological-physical coupled model applied to Station Papa. Journal of Ocean ography, 51, 635-664

Kuma, K., Katsumoto, A., Shiga, N., Sawabe, T., Matsunaga, K., 2000. Variation of size-fractionated Fe concentrations and $\mathrm{Fe}(\mathrm{III})$ hydroxide solubilities during a spring phytoplankton bloom in Funka Bay, Japan. Marine Chemistry, Volume 71, 111-123

Landry, M.R., Barber, R.T., Bidigare, R.R., Chai, F., Coale, K.H., Dam, H.G., Lewis, M.R., Lindley, S.T., McCarthy, J.J., Roman, M.R., Stoecker, D.K., Verity, P.G., White, J.R., 1997. Iron and grazing constraints on primary production in the central equat orial pacific: an EqPac synthesis. Limnology and Oceanography, 42, 405-418

Levitus S., Boyer, T.P., 1994. World Ocean Atlas 1994, Volume 4:Temperat ure. NOAA Atlas NESDIS 4. 117 pp.

Littmann, T., 1991. Dust storm frequency in Asia: Climatic control and variability, Int. J. Climatol., 11, 393-4 12

Martin, J.H., 1992. Iron as a limiting factor in oceanic productivity. In: Falkowski, P.G., Woodhead, A.D., Eds.), Primary Product ivity and Biogeochemical Cycles in the Sea. P lenum Press, New York, pp. 123-137

Martin, J.H., Gordon, R.M., Fitzwater, S.E., 1990. Iron in Antarctic waters. Nature, 345, 156-158

Martin, J.H., Gordon, R.M., Fitzwater, S.E., 1991. The case for iron. Limnology and Oceanography, 36, $1793-1802$

Martin, J.H., Gordon, R.M., Fitzwater, S.E., Broenkow, W.W., 1989. Vertex: phytoplankton/iron studies in the Gulf of Alask a. Deep-Sea Research I, 36, 649-680

Matsumoto, C., Saitoh, S., Takahashi, H., Wakatsuchi, M., 2004. Use of multi-sensor remote sensing to detect seasonal and interannual variability in chlorophyll a distribution in the Sea of Okhotsk. Proceedings of the third workshop on the Okhotsk sea and adjacent areas. PICES Scientific Report, 26, 151-154

Mellor, G. L., Yamada, T., 1982. Development of a turbulence closure model for geophy sical fluid problems. Rev. Geophys. Space Phys., 20, 851-875

Moore J. K., Doneya, S. C., Kleypasa, J. A., Gloverb, D. M., Fungc, I. Y., 2002. An intermediate complex ity marine ecosystem model for the global dom ain. Deep-Sea Research II, 49, 403-462

Moore, J. K., Abbott, M. R., Richman, J. G., Nelson, D. M., 2000. The southern ocean at the last glacial maximum: a strong sink for atmo spheric carbon dioxide. Global Biogeochemical Cycles, 14, 45 5-475

Nakat suka, T., Fujimune, T., Yoshikawa, C., Noriki., S., Kawamura, K., Fukamach, Y., Mizuta, G. and Wakatsuchi, M., 2004. Biogenic and lithogenic particle fluxes in the western region of sea of Okhotsk: imprications 
for lateral material transport and biological productivity, J. Geophys. Res., 109, No. C9, C09S13 doi:10.1029/2003 JC001908

Nishimura, S. 1983. Okhotsk Sea, Japan Sea, Eeast China Sea. P.375-402. In: B.H. Ketchum, Ed.. Ecosystem of the World, Estuaries and Closed Seas. Elsevier Science.

Noiri, Y., Kudo, I., Kiyosawa, H., Nishioka, J., Tsuda, A., 2005. Iron and temperature, two fact ors inXuencing phytoplankton species composition in the westerns subarctic PaciWc Ocean. Progress in Oceanography, $64,149-166$

Ohshima, K. I., M. Wakatsuchi, Y. Fukamachi, and G. Mizuta 2002. Nearsurface circulation and tidal currents of the Okhotsk Sea observed with the satellite-tracked drifters, J. Geophys. Res., 107(C11), 3195, doi:10.1029/2001 JC001005.

Ohwada, M., 1957. Diatom communities in the Okhotsk Sea, principally in the west coast of Kamechaka, spring to summer 1955. Journal of the Oceanographical Society of Japan, 13, 29-34

Okunishi T., Kishi, M. J., Shiomoto, A., Tanaka, H., Yamashita, T., 2005. An ecosystem modeling study of spatio-temporal variations of phytoplankton distribution in the Okhotsk Sea, Continental Shelf Research, 25, 1605-1628

Orlanski IA. 1976. A simple boundary condition for unbounded hyperbolic flows, Journal of Computing Physics, $21,251-269$

Parkinson, C. L. and W. M. Washington, 1979. A large-scale numerical model of sea ice. J. Geophys. Res. 84, $311-337$.

Peña M. A. 2003. Modelling the response of the planktonic food web to iron fertilization and warming in the NE subarct ic Pacific. Progress in oceanography, 57, 453-479

Pollard, D., and S. L. Thompson, 1994. Sea-ice dynamics and $\mathrm{CO}_{2}$ sensitivity in a global climate model. Atmosphere-Ocean 32, 449-467.

Predue, E.H., Beck, K. C. and Reuter, J. H., 1976. Organic complexes of iron and aluminum in natural waters. Nature 260,418-420.

Price, N. M., Ahner, B. A., Morel, F. M. M., 1994. The equatorial Pacific Ocean: grazer-controlled phytoplankt on populations in an iron-limited system. Limnology and Oceanography, 39, 520-534

Reynolds, R.W., Rayner, N.A., Smith, T.M., Stokes, D.C., Wang, W., 2002. An Improved In Situ and Satellite SST Analysis for Climate. J. Climate, 15, 1609-1625 
Rue, E. L., Bruland, K.W., 1995. Complexation of iron(III) by nat ural organic ligands in the Central North Pacific as determined by a new competitive ligand equilibration/adsorptive cathodic stripping voltammetric method. Marine Chemistry, 50, 117-138

Rue, E. L., Bruland, K. W., 1997. The role oforganic complexation on ambient iron chemistry in the equatorial Pacific Ocean and the response ofa mesoscale iron addition experiment. Limnology and Oceanography, 42, 901-910

Saitoh, S., Kishino, M., Kiyofuji, H., Taguchi S., Takahashi, M., 1996. Seasonal variability of phytoplankton pigment concentration in the Okhotsk Sea. Journal of the Remote Sensing Society of Japan, 16, 86-92

Semtner, A. J., 1976. A model for the thermodynamic growth of sea ice in numerical investigations of climate. J. Phys. Oceanogr. 6, 379-389.

Sholkovitz, E.R., 1976. Flocculation of dissolved organic and inorganic matter during the mix ing of river water and seawater. Geochimica et Cosmochimica Acta, 40, 831-845.

Shibata, H., 2005. Process of iron transport from terrestrial ecosystem to river: - Preliminary analysis of spatial and temporal patterns of iron concentration in Amur River -, Proceeding of the Inter national Kyoto Symposium 2005, Report on Amur-Okhotsk Project No.3, December 2005,97-104.

Sorokin, Y. I. Sorokin P. Y., 1999. Production in the Sea of Okhotsk, Journal of P lankton Research, 21, 201-230

Sorokin, Y. I. Sorok in P. Y., 2002. Microplankton and primary production in the Sea of Okhot sk in summer 1994. Journal of P lankton Research, 24, 453-470

Takeda, S., Obata, H., 1995. Response of equatorial pacific phytoplankton to subnanomolar Fe enrichment. Marine Chemistry, 50, 219-227

Takeda, S.,, 1998. Influence of iron availability on nutrient consumption ratio of diatoms in oceanic waters. Nature, 393, 774-777

Tani, H., Nishioka, J., Kuma, K., Takata, H., Yamashita, Y., Tanoue, E., Midorikawa, T., 2003. Iron(III) hydroxide solubility and humic-type fluorescent organic matter in the deep water column of the Okhotsk Sea and the northwestern North Pacific Ocean. Deep-Sea Research I, 50, 1063-1078

Tsuda, A., Takeda, S., Saito, H., Nishioka, J., Nojiri, Y., Kudo, I., Kiyosawa, H., Shiomoto., A. Imai, K. Ono, T. Shimamoto, A. Tsumune., D., Yoshimura, T., Aono, T. Himuma, A., Kinugasa, M., Suzuki, K., Sohrin, Y., Noiri, Y., Tani, H., Deguchi, Y., Tsurushima, N., Ogawa, H., Fukami, K., Kuma, K. Saino, T., 2003. A mesoscale iron enrichment in the western subarctic Pacific induces a large centric diatom bloom. 
Science, 300, 958-961

Yoshie N., Fujii M., Yamanaka Y., 2005. Ecosystem changes after the SEEDS iron fertilization in the western North Pacific simulated by a one-dimensional ecosystem model. Progress in oceanography, 64, 283-306

van den Berg, C. M. G., 1995. Evidence for organic complexation of iron in seawater. Marine Chemistry, 50, $139-157$

Wang, J., Q. Liu, M. Jin, M. Ikeda, F. J. Saucier, 2005. A coupled ice-ocean model in the Pan-Arctic and North Atlantic Ocean: simulation of seasonal cycles. Journal of Oceanography, 61, 213-233

Wroblewski, J. S., 1977. A model of phytoplankton plume formation during Oregon upwelling. J. Mar. Res., 35, 357-394 
Table 1. The ecological model parameters values.

\begin{tabular}{|c|c|c|c|}
\hline $\mathrm{V}_{\max }$ & Max Photo synthesis Rate at $0^{\circ} \mathrm{C}$ & 0.5 & /day \\
\hline $\mathrm{k}$ & $\mathrm{k}$ Temperature Coefficient for Photosynthetic Rate & 0.063 & $/{ }^{\circ} \mathrm{C}$ \\
\hline $\mathrm{I}_{\mathrm{opt}}$ & Optimum Light Intensity & 80 & $\mathrm{~W} / \mathrm{m}^{2}$ \\
\hline $\mathrm{K}_{\mathrm{I}}$ & Half saturation coefficient for light intensity. & 0.0336 & $\mathrm{~W} / \mathrm{m}^{2}$ \\
\hline$\alpha_{1}$ & Light Dissip ation Coefficient of Sea Water & 0.035 & $/ \mathrm{m}$ \\
\hline$\alpha 2$ & Self Shad ing Coefficient & 0.0281 & $1 / \mu \mathrm{molN} \mathrm{m}$ \\
\hline$\Psi$ & Ammonium Inhibition Coefficient & 1.5 & $1 / \mu \mathrm{mol}$ \\
\hline $\mathrm{K}_{\mathrm{NO} 3}$ & Half Saturation Coefficient for Nitrate & 3.0 & $\mu \mathrm{mol} / 1$ \\
\hline $\mathrm{K}_{\mathrm{NH} 4}$ & Half Saturation Coefficient for Ammonium & 0.5 & $\mu \mathrm{mol} / 1$ \\
\hline $\mathrm{K}_{\mathrm{Fe}}$ & Half Saturation Coefficient for iron & 0.58 & $\mathrm{nmol} / 1$ \\
\hline FENR & $\mathrm{Fe} / \mathrm{N}$ Ratio to Phytoplankton & 0.044 & $\mathrm{nmol} / \mu \mathrm{mol}$ \\
\hline $\mathrm{M}_{\mathrm{P} 0}$ & Phytoplankton Mortality Rate at $0^{\circ} \mathrm{C}$ & 0.0281 & $1 / \mu \mathrm{molN}$ day \\
\hline $\mathrm{k}_{\mathrm{MP}}$ & Temperature Coefficient for Phytoplankton Mortality & 0.069 & $/{ }^{\circ} \mathrm{C}$ \\
\hline $\mathrm{M}_{\mathrm{Z} 0}$ & Zooplankton Mortality Rate at $0^{\circ} \mathrm{C}$ & 0.0585 & $1 / \mu \mathrm{molN}$ day \\
\hline $\mathrm{k}_{\mathrm{MZ}}$ & Temperature Coefficient for Zooplankton Mortality & 0.0693 & $/{ }^{\circ} \mathrm{C}$ \\
\hline$\gamma$ & Ratio of Extracelluler Excretion to Photo synthesis & 0.135 & - \\
\hline $\mathrm{GR}_{\max }$ & Max Grazing Rate at $0^{\circ} \mathrm{C}$ & 0.30 & /day \\
\hline $\mathrm{kg}$ & Temperature Coefficient for Grazing & 0.0693 & $1{ }^{\circ} \mathrm{C}$ \\
\hline$\lambda$ & Ivlev Constant & 1.4 & $1 / \mu \mathrm{molN}$ \\
\hline $\mathrm{Ch} l^{*}$ & Threshold Value for Grazing & 0.043 & $\mu \mathrm{molN} / 1$ \\
\hline$\alpha$ & Assimilation Efficiency of Zooplankton & 0.7 & - \\
\hline$\beta$ & Growth Efficiency of Zooplankton & 0.3 & - \\
\hline $\mathrm{V}_{\mathrm{PI} 0}$ & Dtritus Decompo sition Rate at $0^{\circ} \mathrm{C}$ (to Inorganic Nitrogen) & 0.030 & ${ }^{\circ} \mathrm{C}$ \\
\hline$V_{\text {PIT }}$ & Temperature Coefficient for Dtritus Decomposition (to Inorganic Nitrogen) & 0.0693 & /day \\
\hline $\mathrm{V}_{\mathrm{PD} 0}$ & Dtritus Decomposition Rate at $0^{\circ} \mathrm{C}$ (to DON) & 0.030 & $/{ }^{\circ} \mathrm{C}$ \\
\hline $\mathrm{V}_{\text {PDT }}$ & VPDT Temperature Coefficient for Dtritus Decomposition (to DON) & 0.0693 & /day \\
\hline $\mathrm{V}_{\mathrm{DI} 0}$ & VDI0 DON Decomposition Rate at $0^{\circ} \mathrm{C}$ & 0.030 & $/{ }^{\circ} \mathrm{C}$ \\
\hline $\mathrm{V}_{\text {DIT }}$ & VDIT Temperature Coefficient for DON Decompo sition & 0.0693 & /day \\
\hline $\mathrm{k}_{\mathrm{N} 0}$ & kN0 Nitrification Rate at $0^{\circ} \mathrm{C}$ & 0.030 & $/{ }^{\circ} \mathrm{C}$ \\
\hline $\mathrm{k}_{\mathrm{NT}}$ & kNT Temperature Coefficient for Nitrification & 0.0693 & /day \\
\hline S & Sinking velocity of Dtritus & 10 & $\mathrm{~m} /$ day \\
\hline
\end{tabular}


Table 2. Annual Primary Production in the Okhotsk Sea in 2001 from the model results of each simulation case. The KKYS-Fe's results is divided by the use situation of each iron compartments.

\begin{tabular}{lccccccccc}
\hline \hline & $\begin{array}{c}\text { KKYS-Fe } \\
\text { (Case1) }\end{array}$ & \multicolumn{2}{c}{$\begin{array}{c}\text { KKYS-Fe } \\
\text { (Case2) }\end{array}$} & $\begin{array}{c}\text { KKYS-Fe } \\
\text { (Case3) }\end{array}$ & \multicolumn{2}{c}{$\begin{array}{c}\text { KKYS-Fe } \\
\text { (Case4) }\end{array}$} & KKYS \\
& $\mathrm{gC} \mathrm{m}^{-2}$ year $^{-1}$ & $\%$ & $\mathrm{gC} \mathrm{m}^{-2}$ year $^{-1}$ & $\%$ & $\mathrm{gC} \mathrm{m}^{-2}$ year $^{-1}$ & $\%$ & $\mathrm{gC} \mathrm{m}^{-2}$ year $^{-1}$ & $\%$ & ${ }_{2} \mathrm{C} \mathrm{m}^{-2}$ year $^{-1}$ \\
\hline \hline $\mathrm{FE}_{\mathrm{AIR}}$ & 103 & 33 & 59 & 21 & 96 & 34 & 98 & 31 & \\
$\mathrm{FE}_{\mathrm{RIV}}$ & 8 & 2.6 & 9 & 3.1 & 9 & 3.0 & 29 & 9.2 & \\
$\mathrm{FE}_{\mathrm{SED}}$ & 99 & 32 & 109 & 38 & 38 & 13 & 92 & 29 & \\
$\mathrm{FE}$ & 100 & 32 & 106 & 38 & 140 & 50 & 96 & 30 & \\
total & 310 & - & 283 & - & 281 & - & 315 & - & 382 \\
\hline \hline
\end{tabular}




\section{Figure captions}

Fig.1

Study area and bathymetry in the Okhotsk Sea. Contour intervals are $500 \mathrm{~m}$. Five Stations (Sta. A, B, C, E, D) in the figure are used in Figures 6 and 8.

Fig.2

Schematic view of the ecological model (KKYS-Fe). Boxes represent nitrogen-based and iron-based compartments and arrows represent nitrogen and iron flows through the ecosy stem.

Fig.3

Schematic diagram of the process of dissolved iron supply to the Okhotsk Sea. Four processes of dissolved iron supply to the Okhotsk Sea are assumed: 1) atmospheric loadings from Northeastern Asia $\left(\mathrm{FE}_{\mathrm{AIR}}\right)$, 2) riverine inputs from the Amur River ( $\left.\mathrm{FE}_{\mathrm{RIV}}\right)$, 3) dissolution from sediments $\left(\mathrm{FE}_{\mathrm{SED}}\right)$, and 4) biological regeneration by zooplankton and bacteria $\left(\mathrm{FE}_{\mathrm{BIO}}\right)$. Our model considers $\mathrm{FE}_{\mathrm{RIV}}$ as a "direct contribution" from the Amur River. The particulate iron has the potential to supply dissolved iron to the water column by resolution. The model does not consider iron removed by flocculation at the river mouth. We can say that the contribution of resolved iron from the particulate iron supply of the Amur River is an "indirect contribution".

Fig.4

Annual mean atmospheric iron flux $\left(\mathrm{mmol} \mathrm{m}^{-2} \mathrm{year}^{-1}\right)$ in the model.

Fig.5

Monthly mean discharge of the Amur River (Komsomolsk) from 1933 to 1990 from the Global Runoff Data Center.

Fig. 6

Vertical profile of the in itial $\mathrm{FE}_{\mathrm{BIO}}$ concentration.

Fig.7

Time-dependent features of each compartment at the sea surface at Sta. C from KKYS-Fe for two y ears. The first-y ear results (DAY $=0$-365) are a sp in-up integration, the second-y ear results (DAY=365-730) are used for model analysis. The time constants of this ecosy stem model are less than 160 days. The right-side scale is for $\mathrm{NO}_{3}$ concentrations, and left-side scale is for the concentrations of the other compartments.

Fig. 8 
Monthly mean sea ice concentrations from (a) NCEP data (Reynolds et al., 2002), (b) the model results.

Fig.9

The time-dependent features of Chl-a and nitrate concentrations in the surface layer $(20 \mathrm{~m})$ at five study points shown in Fig.1. Left figures show the Chl-a concentrations from SeaWiF S data, KKYS-Fe, KKYS. Right figures show the nitrate concentrations from the World Ocean Atlas 2001 data, KKYS-Fe, KKYS.

Fig.10

Monthly mean nitrate concentration in M arch from (a) the World Ocean Atlas 2001 data, (b) KKYS-Fe and (c) KKYS in surface water (averaged from $0 \mathrm{~m}$ to $20 \mathrm{~m}$ ).

Fig.11

Same as Fig.10 but for July.

Fig.12

Monthly mean Chl-a concentration in May from (a) seaWiFs-Chl image, (b) KKYS-Fe and (c) KKYS in surface water (averaged from $0 \mathrm{~m}$ to $20 \mathrm{~m}$ ).

Fig.13

Same as Fig.12 but for June.

Fig.14

Simulated (a) $\mathrm{FE}_{\mathrm{AIR}}$, (b) $\mathrm{FE}_{\mathrm{SED}}$, (c) $\mathrm{FE}_{\mathrm{BIO}}$, and (d) $\mathrm{FE}_{\mathrm{RIV}}$ concentration in June from KKYS-Fe. The model results are averaged from $0 \mathrm{~m}$ to $20 \mathrm{~m}$. The domain of (d) is described only near the mouth of the Amur River, because concentrations in other areas are nearly zero.

Fig.15

Horizontal distribution of the annual primary production $\left(\mathrm{g}-\mathrm{C} \mathrm{m}^{-2} \mathrm{year}^{-1}\right)$ in 2001 from KKYS-Fe

Fig.16

Horizontal distribution of the difference in annual primary p roduction between KKYS and KKYS-Fe (g-C m ${ }^{-2}$ y ear $\left.^{-1}\right)$.

Fig.17

The time-dependent features of the contribution ratio from each source of iron to total photosynthesis in the Okhotsk Sea. 


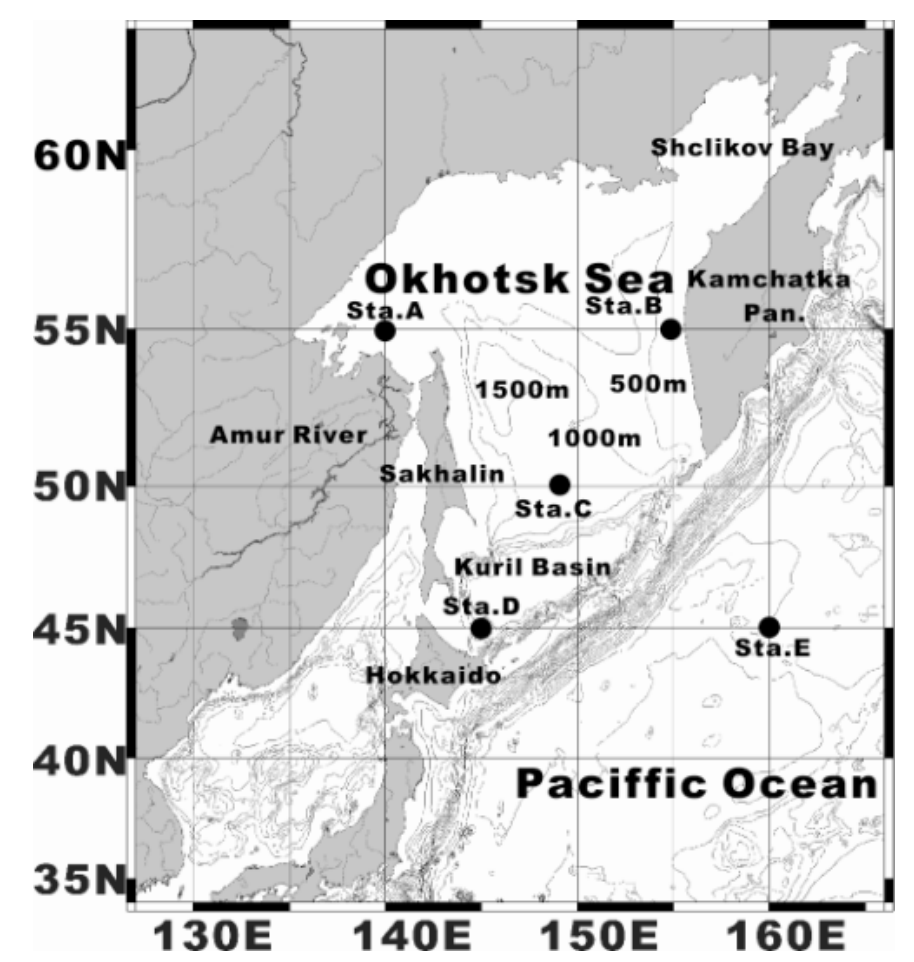

Fig. 1 


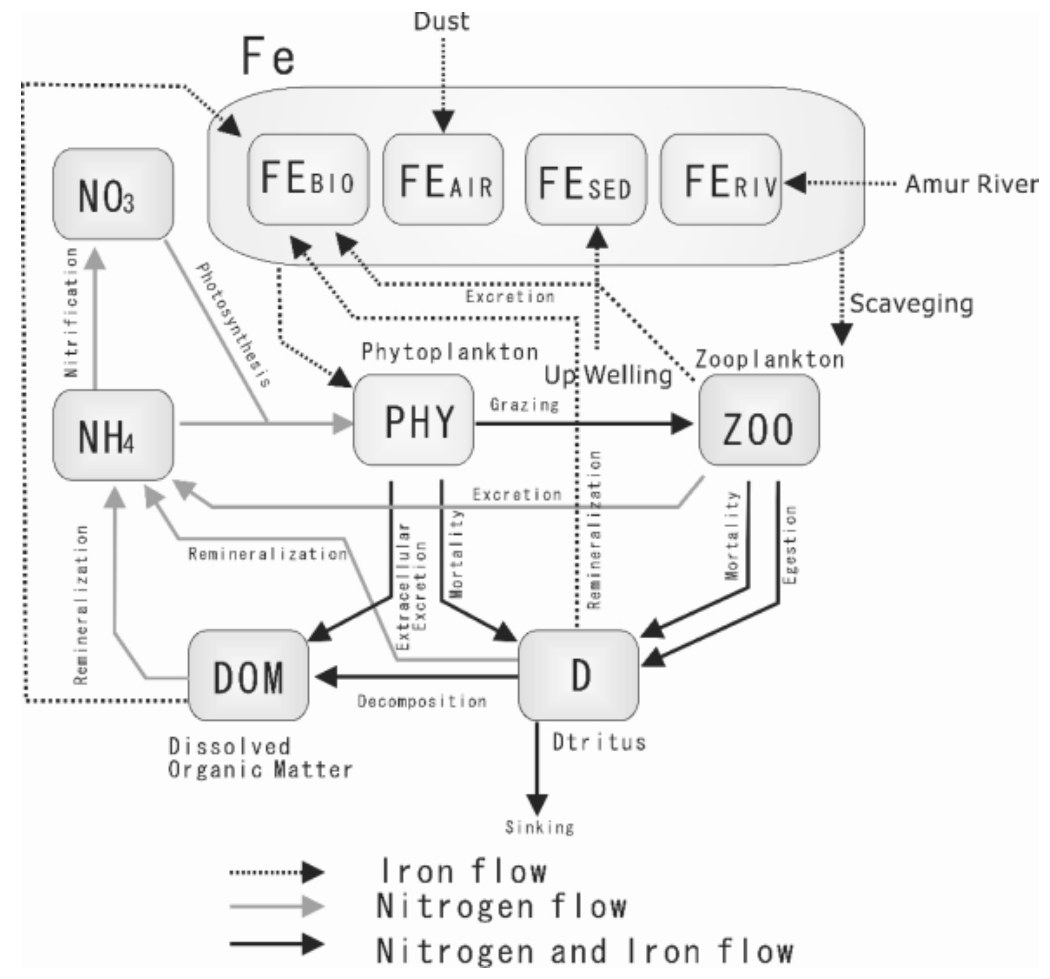

Fig. 2 
Atmospheric dust

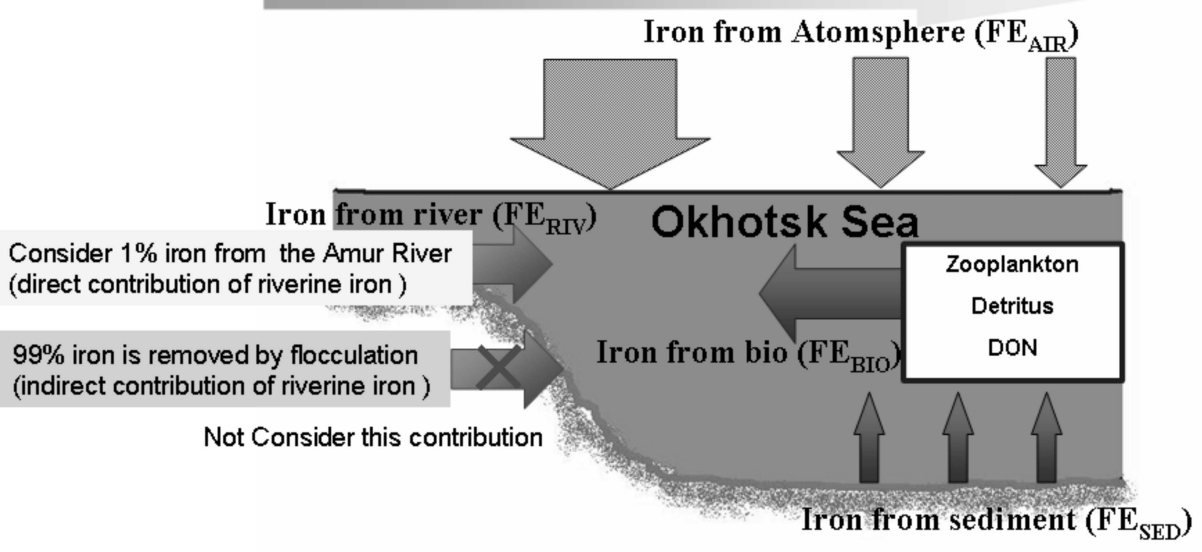

Fig. 3 


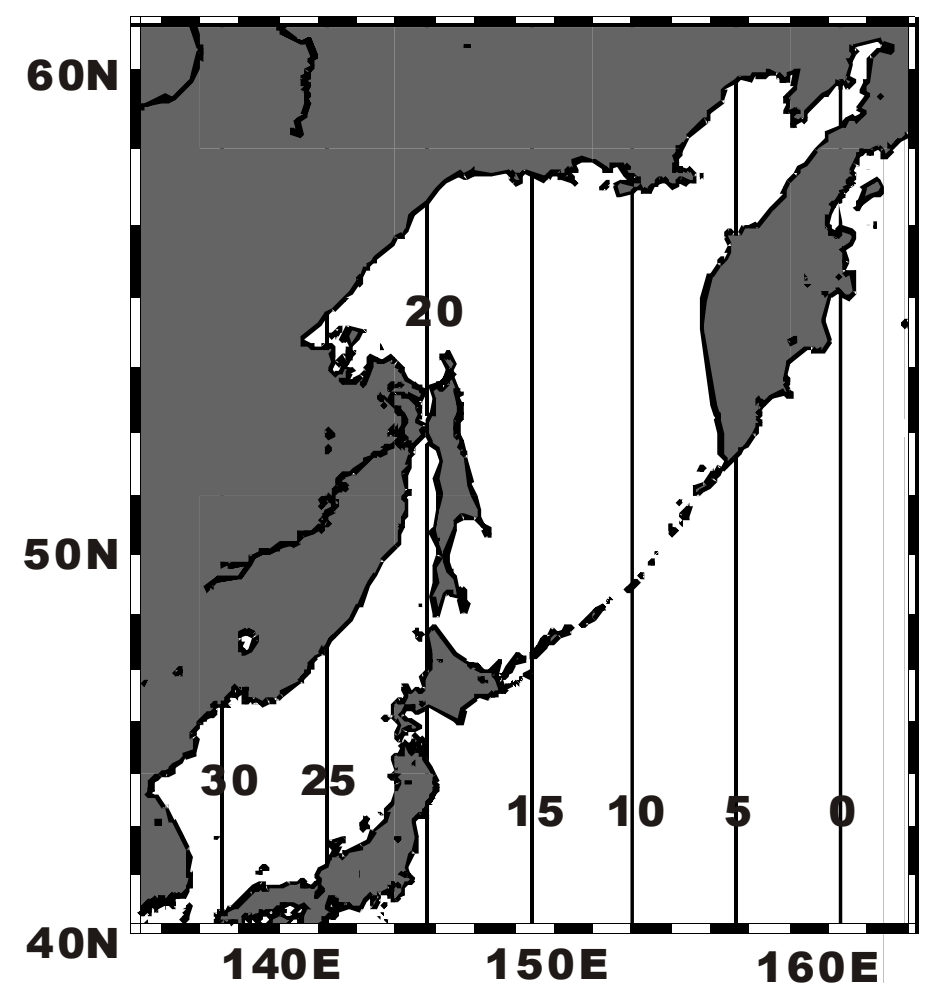

Fig. 4 


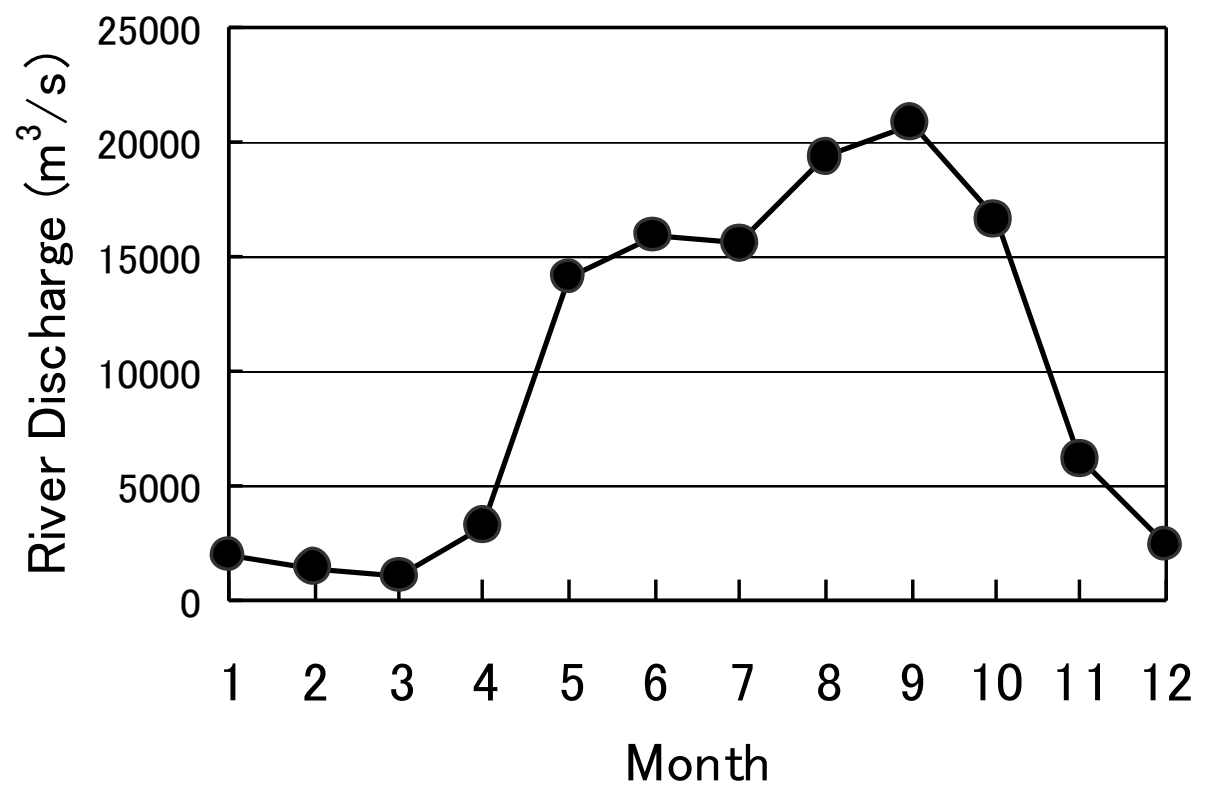

Fig. 5 


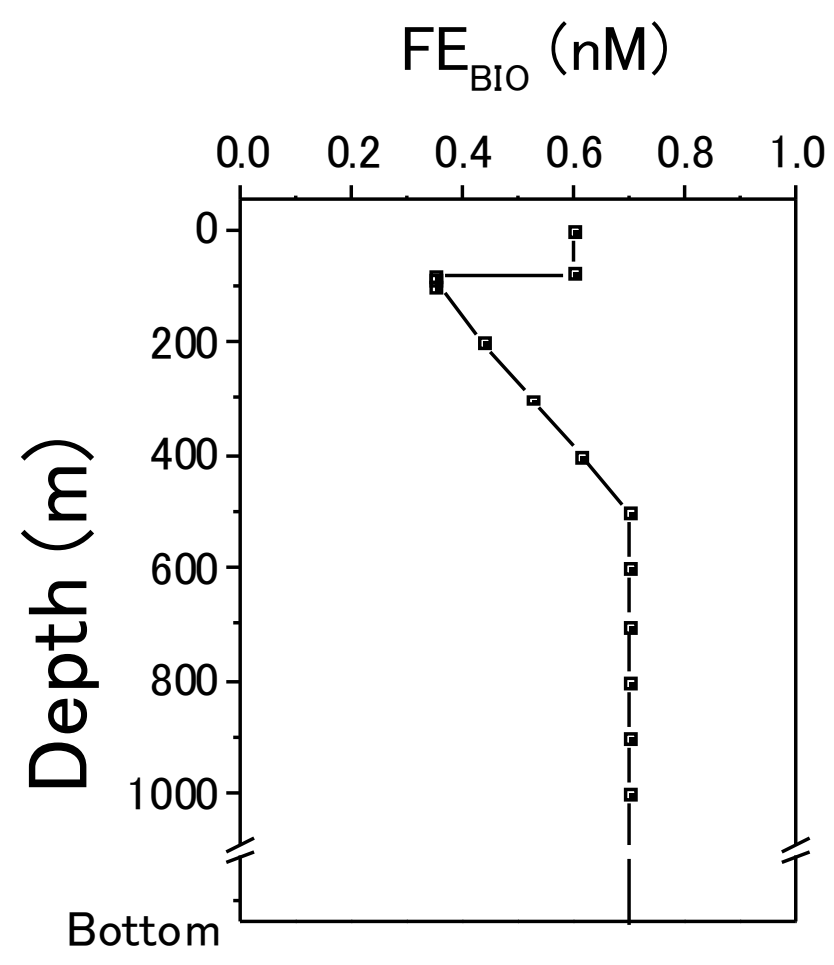

Fig. 6 


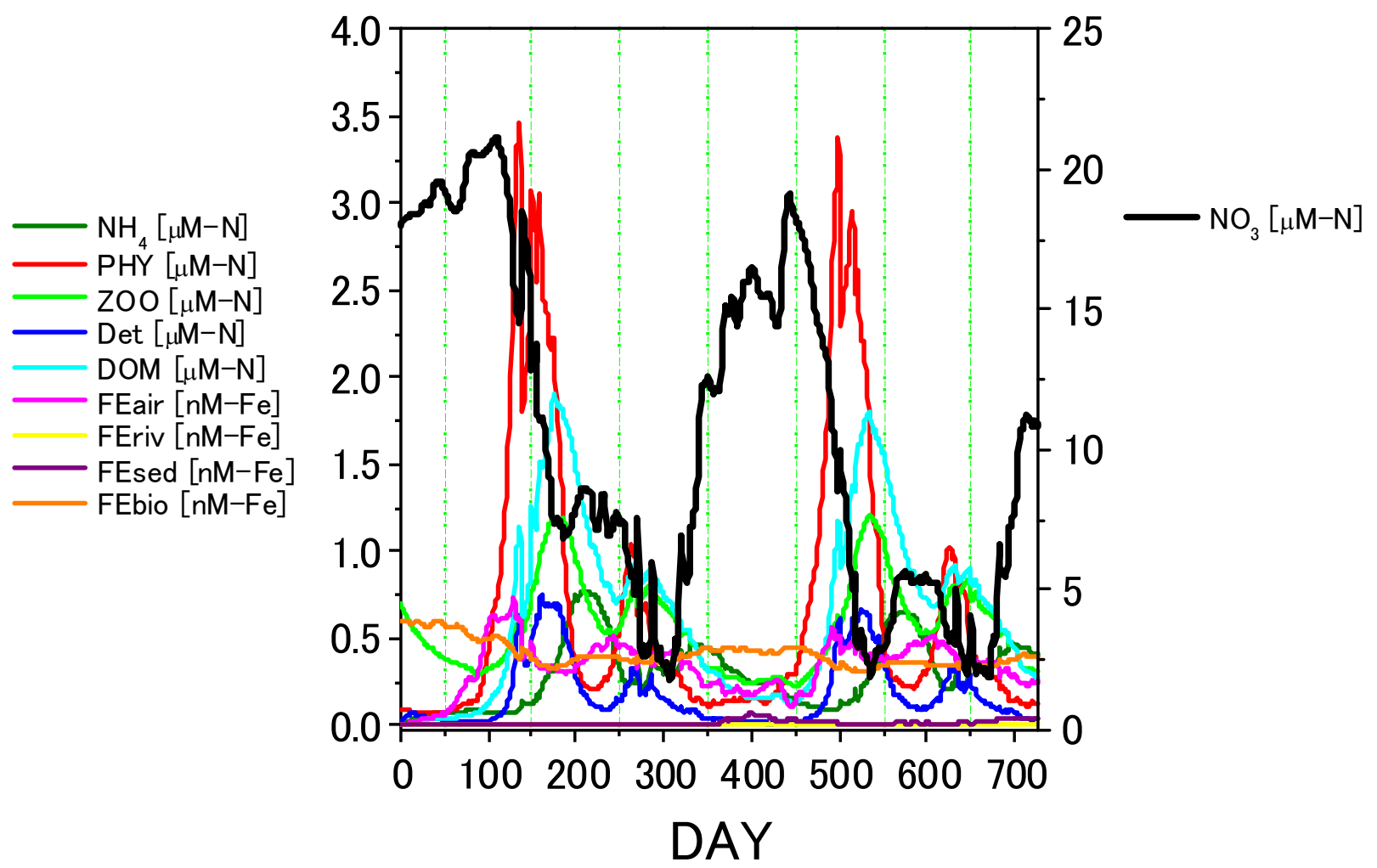

Fig. 7 


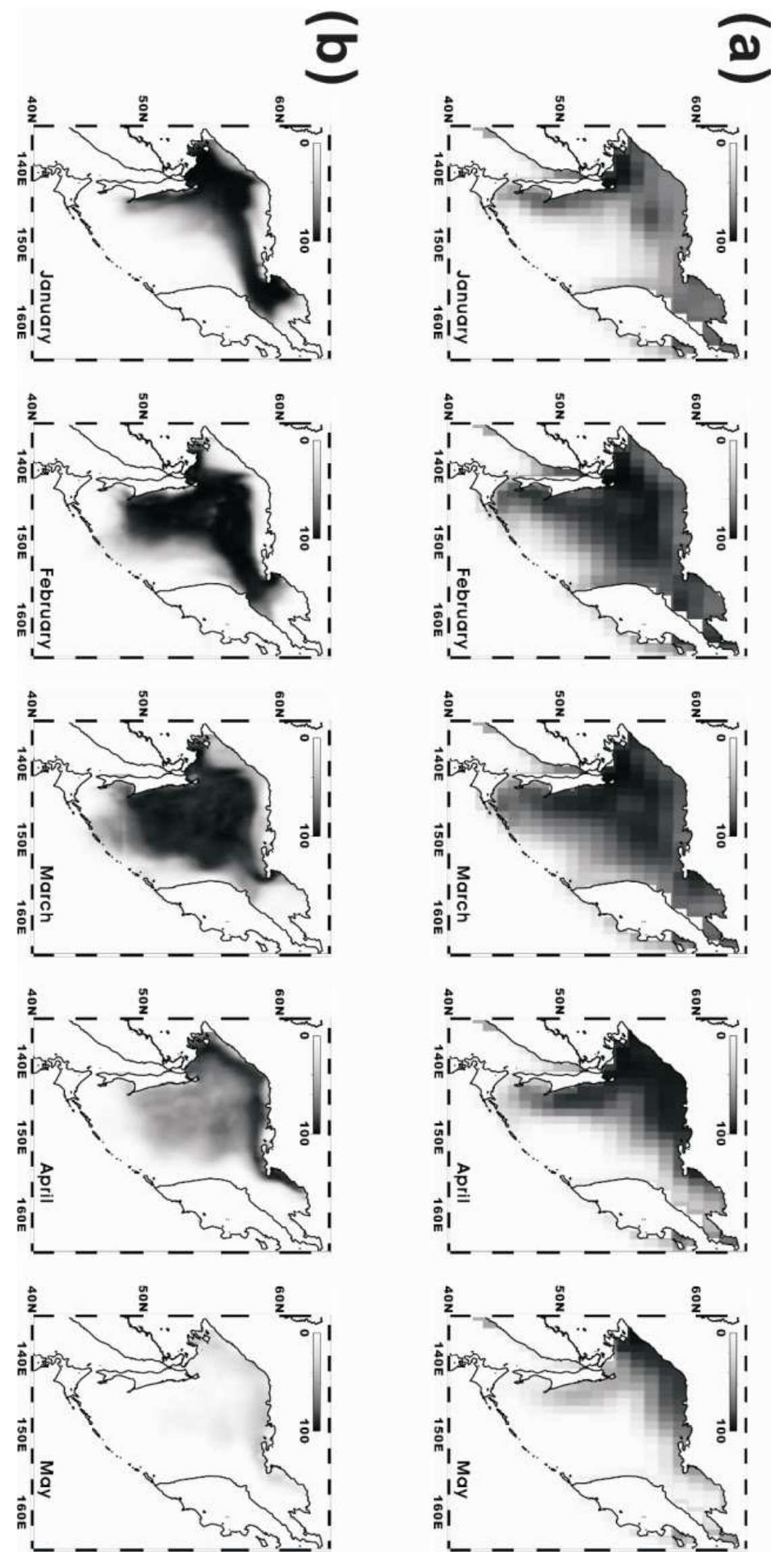


Fig. 8
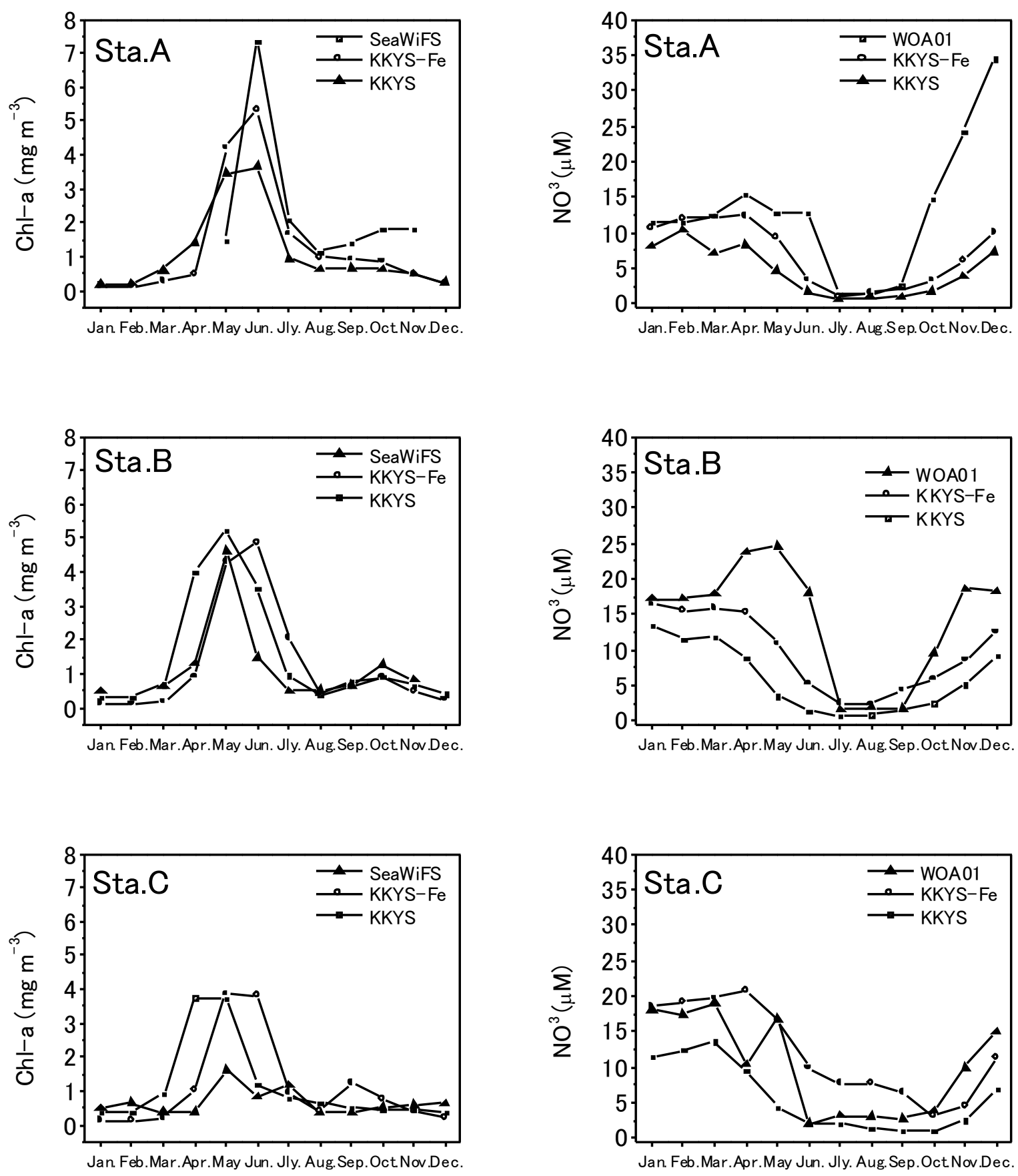

Fig. 9-1 

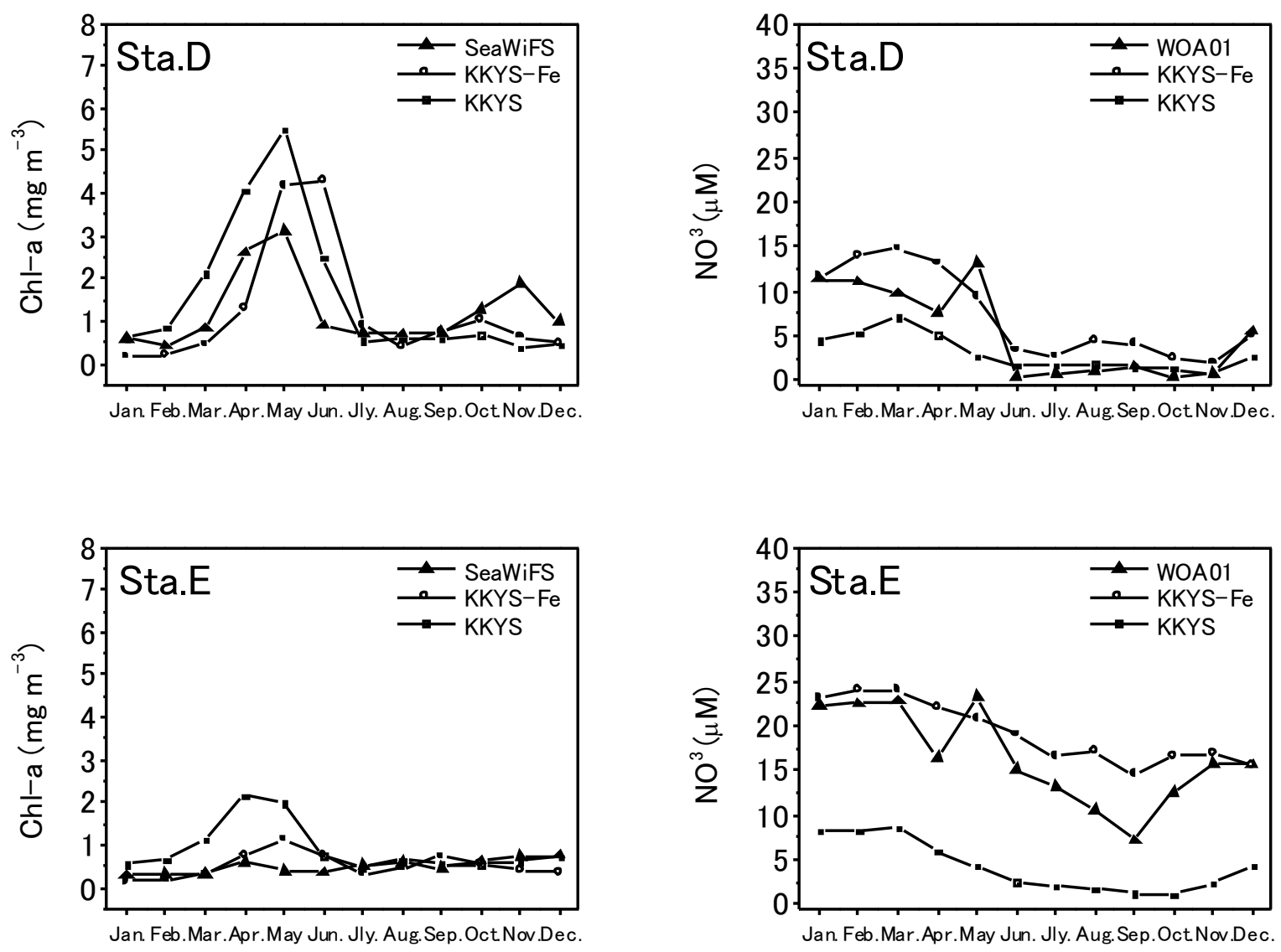

Fig. 9-2 
(a)

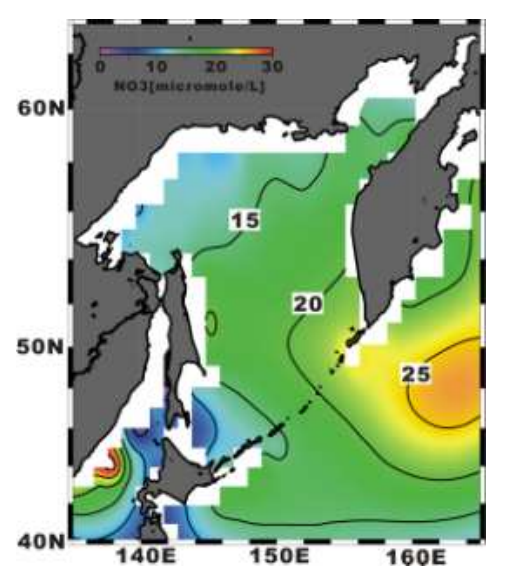

Fig. 10

(a)

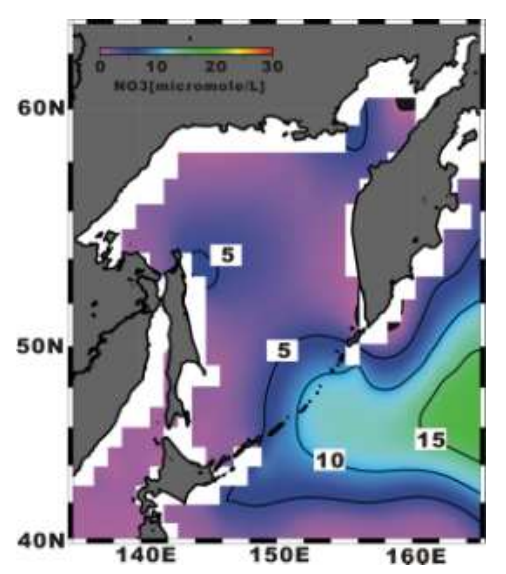

(b)

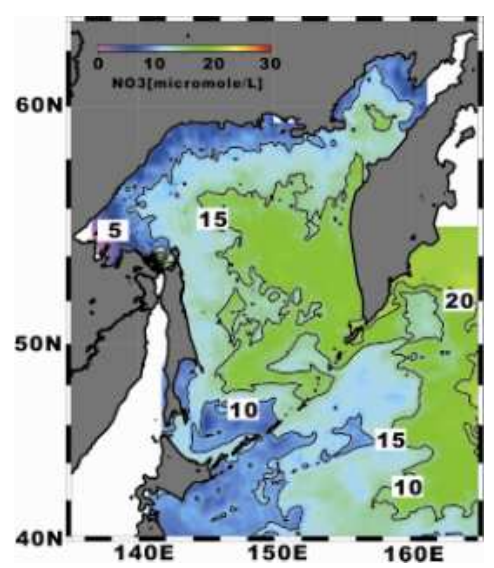

(c)

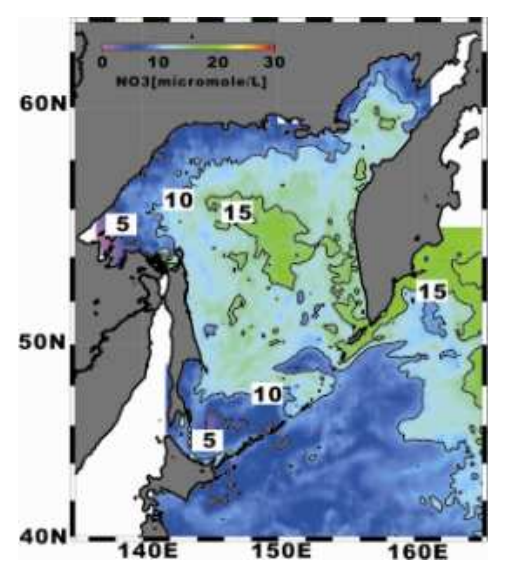

(b)

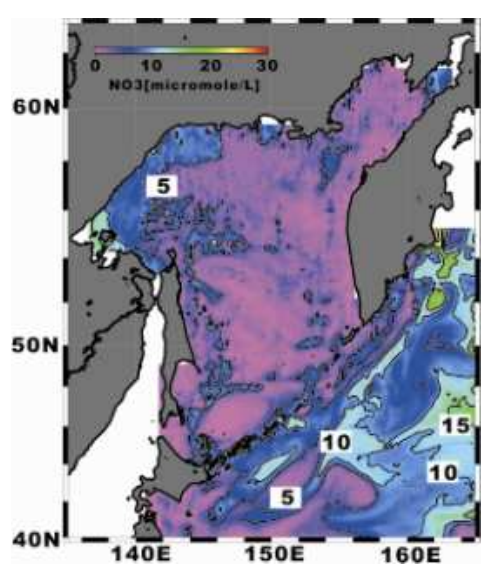

(c)

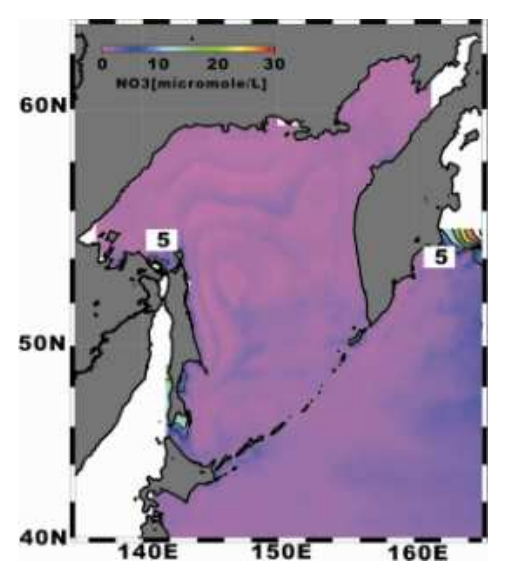

Fig. 11 
(a)

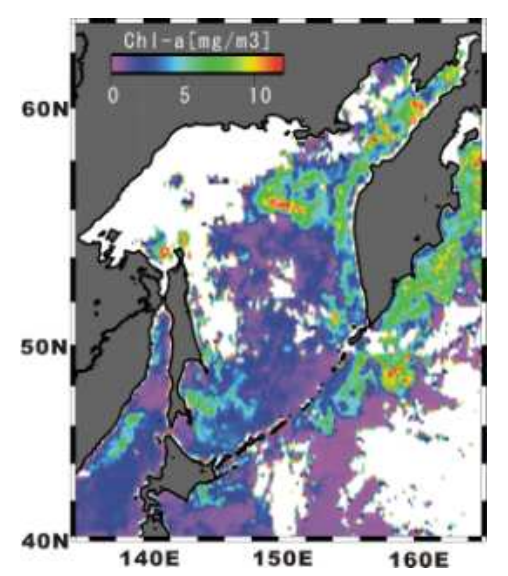

(b)

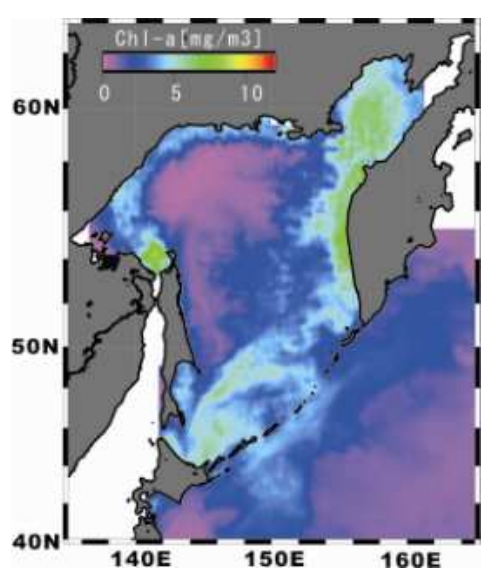

(c)

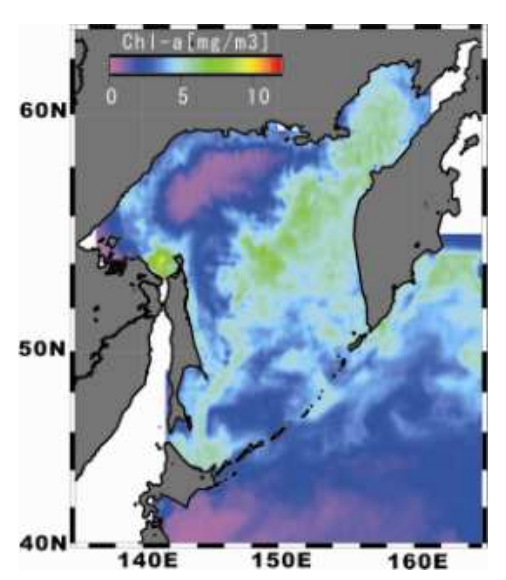

Fig. 12 
(a)

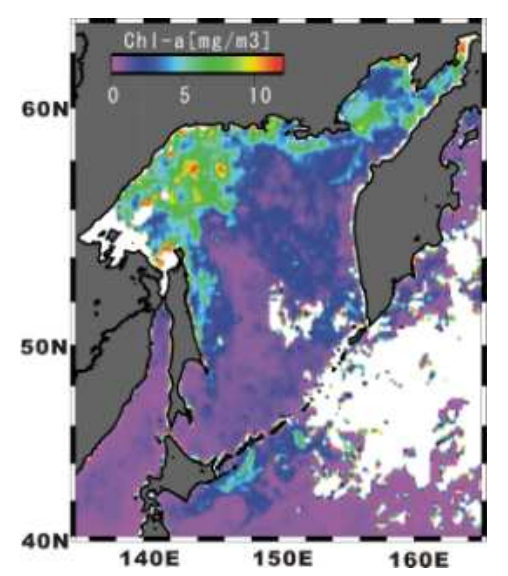

(b)

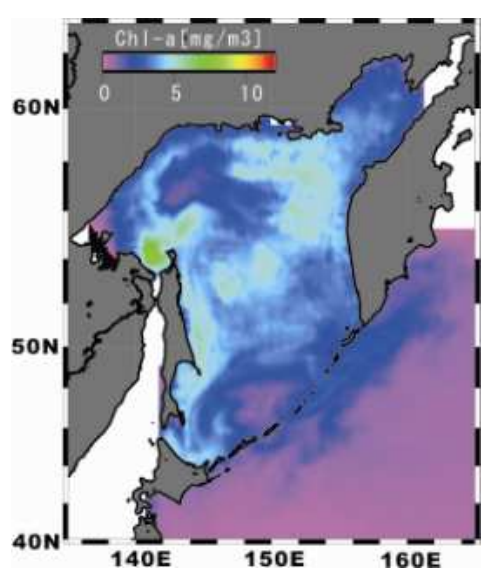

(c)

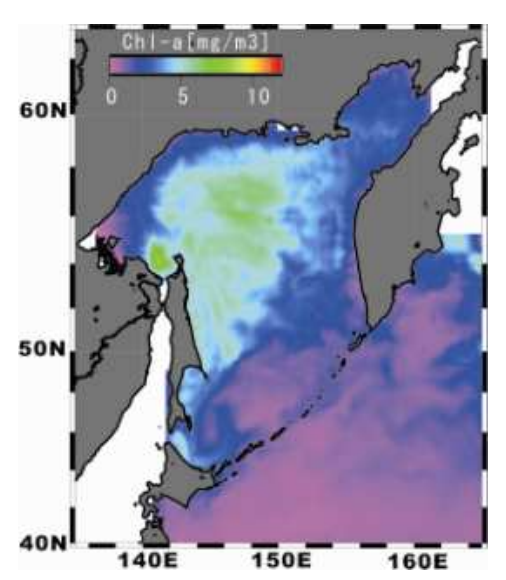

Fig. 13 
(a)

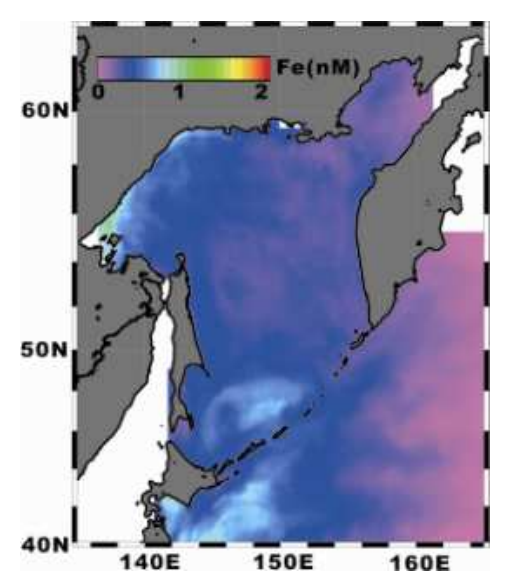

(d)

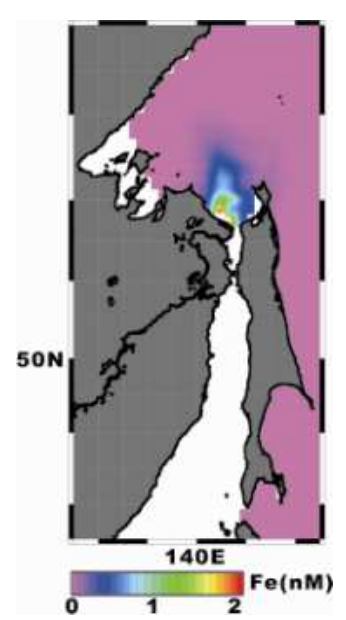

Fig. 14 (b)

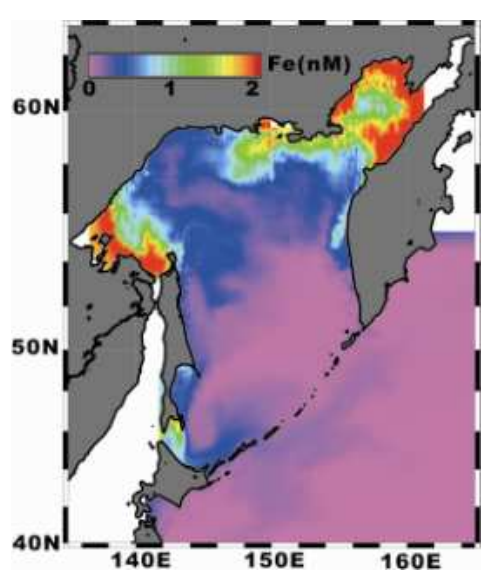

(c)

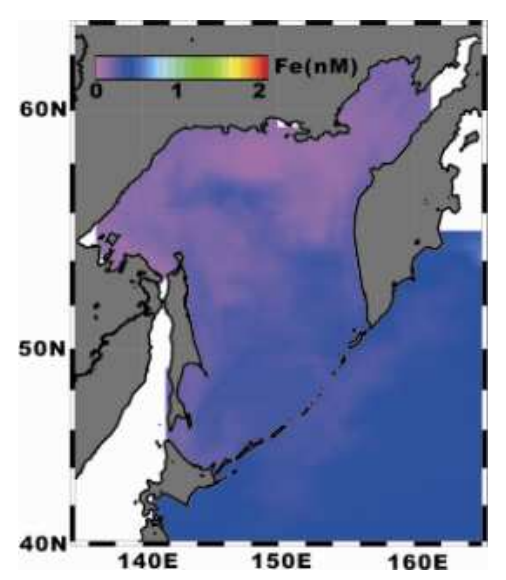




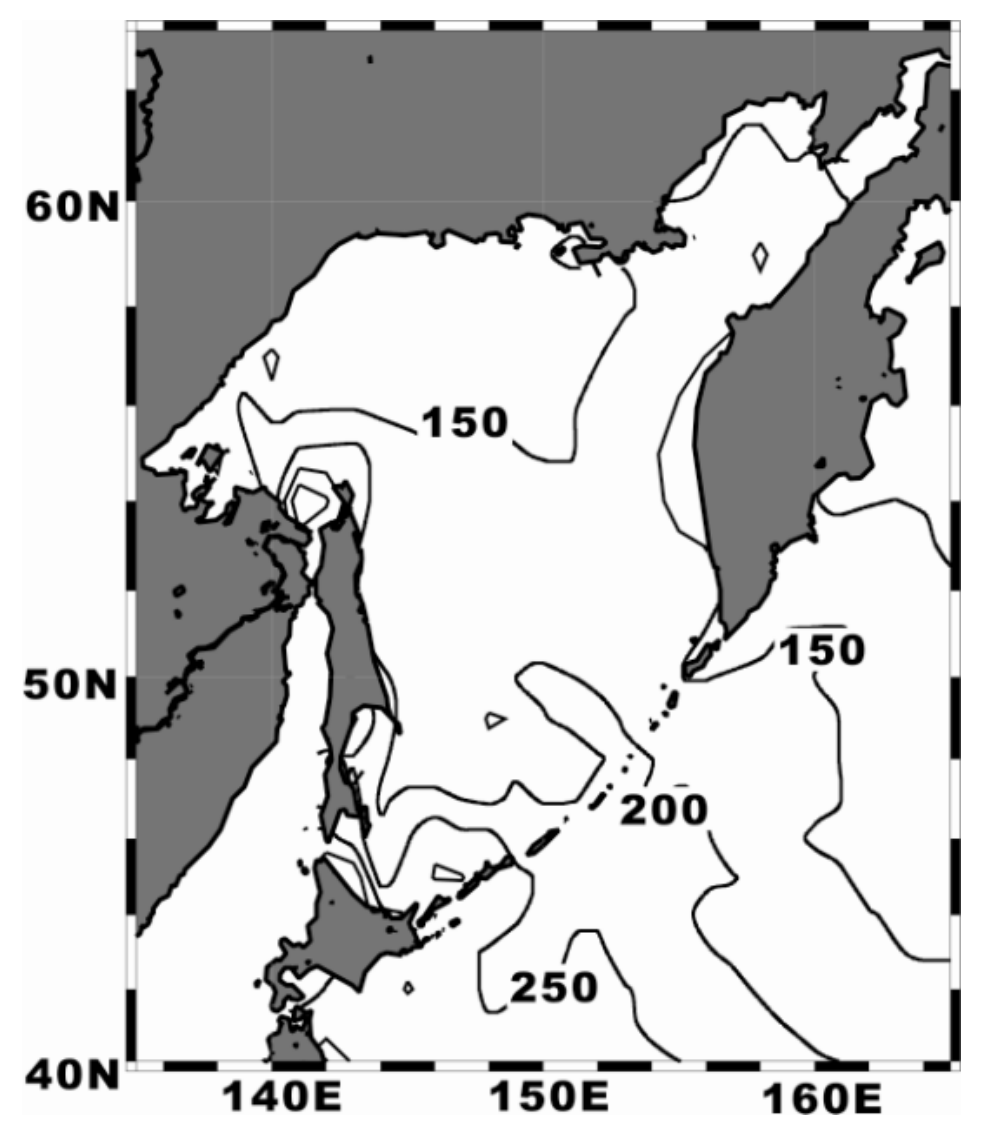

Fig. 15 


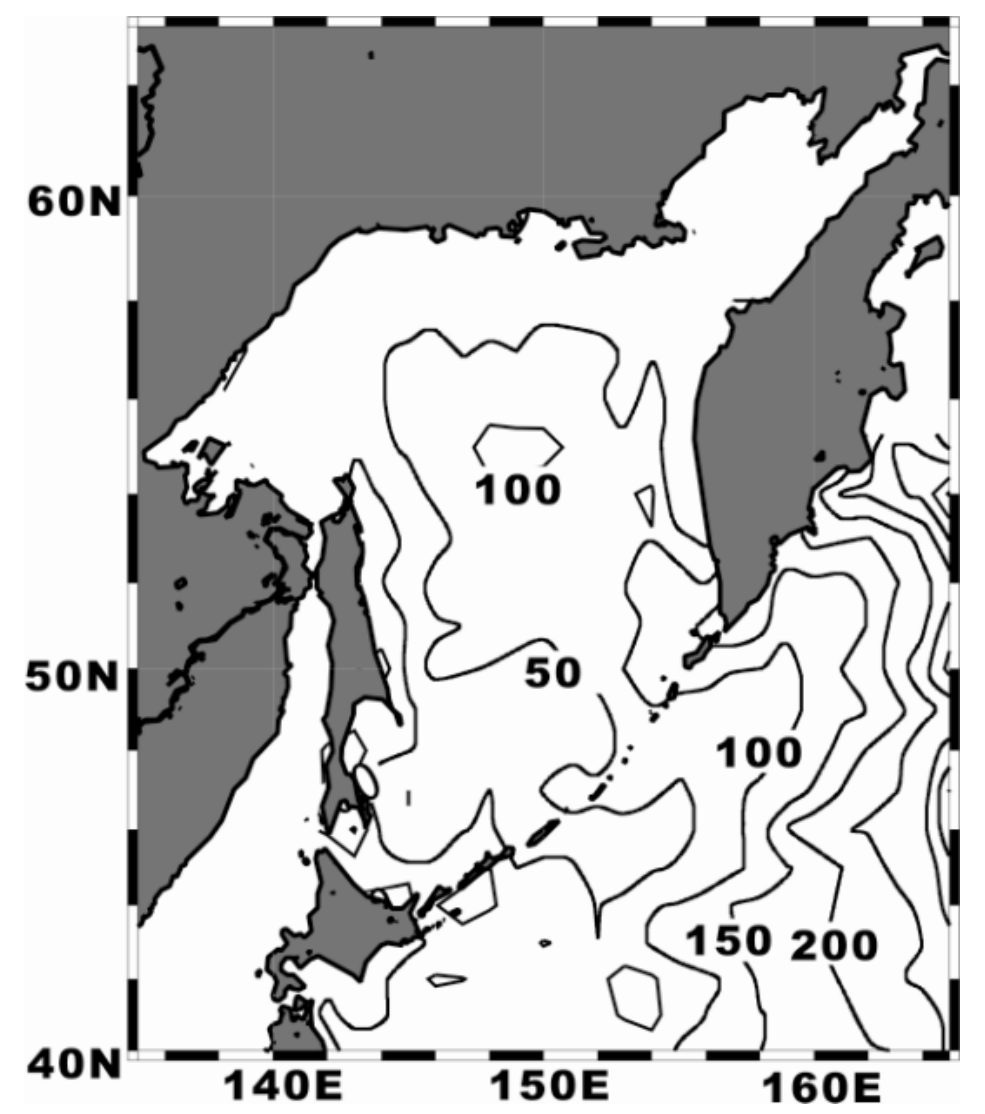

Fig. 16 


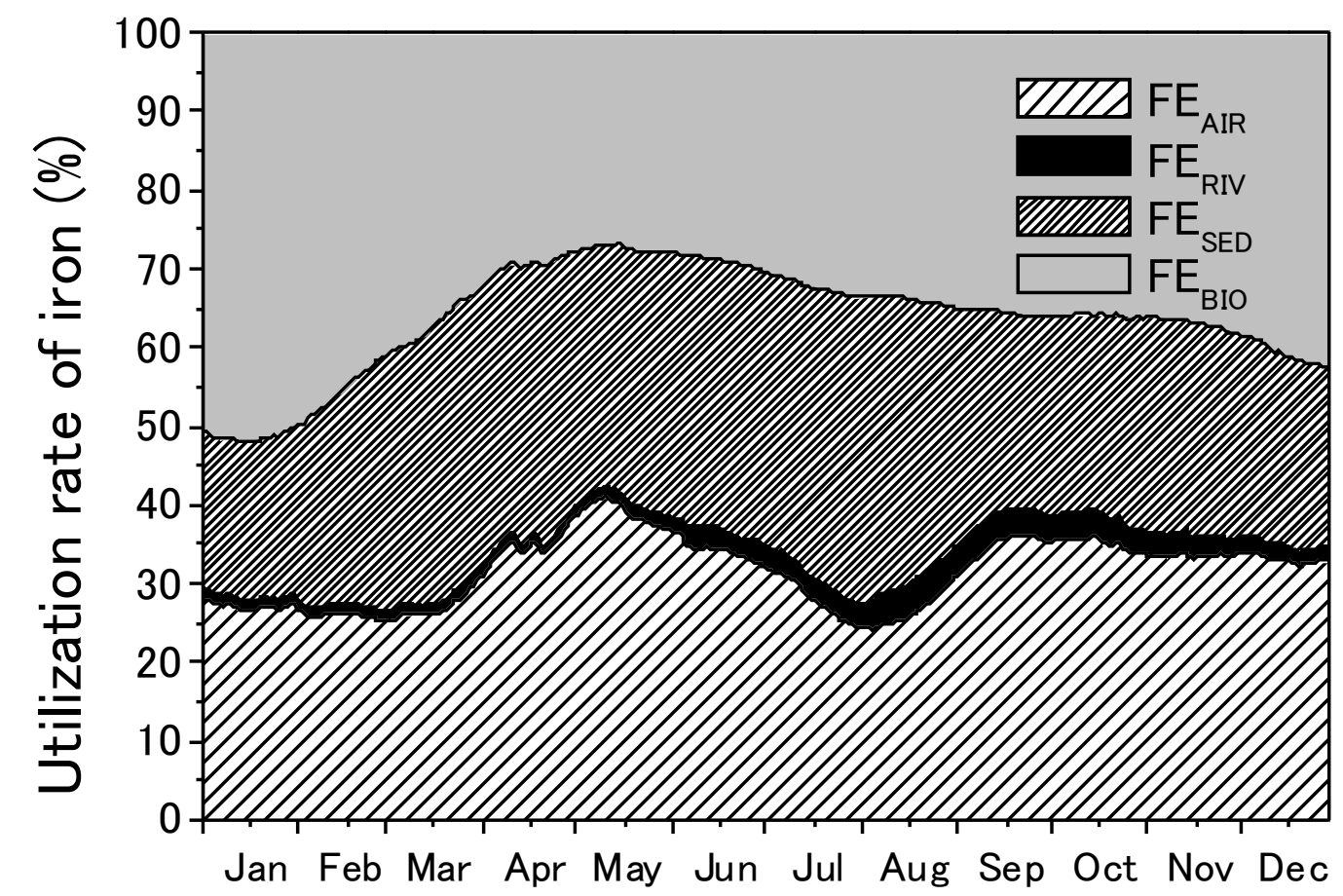

Fig. 17 